\title{
57736
}

\section{Integration with the}

\section{Global Economy: The Case of}

Turkish Automobile and Consumer Electronics Industries 

COMMISSION

ON GROWTH

DEVElopment

\section{Integration with the \\ Global Economy: The Case of Turkish Automobile and Consumer Electronics Industries}

Erol Taymaz

Kamil Yilmaz

Australian Government

DFID

Dutch Ministry

of Foreign Affairs

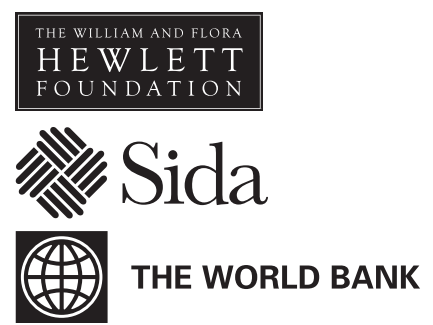


(C) 2008 The International Bank for Reconstruction and Development / The World Bank

On behalf of the Commission on Growth and Development

1818 H Street NW

Washington, DC 20433

Telephone: 202-473-1000

Internet: www.worldbank.org

www.growthcommission.org

E-mail: info@worldbank.org

contactinfo@growthcommission.org

All rights reserved

1234511100908

This working paper is a product of the Commission on Growth and Development, which is sponsored by the following organizations:

Australian Agency for International Development (AusAID)

Dutch Ministry of Foreign Affairs

Swedish International Development Cooperation Agency (SIDA)

U.K. Department of International Development (DFID)

The William and Flora Hewlett Foundation

The World Bank Group

The findings, interpretations, and conclusions expressed herein do not necessarily reflect the views of the sponsoring organizations or the governments they represent.

The sponsoring organizations do not guarantee the accuracy of the data included in this work. The boundaries, colors, denominations, and other information shown on any map in this work do not imply any judgment on the part of the sponsoring organizations concerning the legal status of any territory or the endorsement or acceptance of such boundaries.

All queries on rights and licenses, including subsidiary rights, should be addressed to the Office of the Publisher, The World Bank, 1818 H Street NW, Washington, DC 20433, USA; fax: 202-522-2422; e-mail: pubrights@worldbank.org.

Cover design: Naylor Design 


\section{About the Series}

The Commission on Growth and Development led by Nobel Laureate Mike Spence was established in April 2006 as a response to two insights. First, poverty cannot be reduced in isolation from economic growth - an observation that has been overlooked in the thinking and strategies of many practitioners. Second, there is growing awareness that knowledge about economic growth is much less definitive than commonly thought. Consequently, the Commission's mandate is to "take stock of the state of theoretical and empirical knowledge on economic growth with a view to drawing implications for policy for the current and next generation of policy makers."

To help explore the state of knowledge, the Commission invited leading academics and policy makers from developing and industrialized countries to explore and discuss economic issues it thought relevant for growth and development, including controversial ideas. Thematic papers assessed knowledge and highlighted ongoing debates in areas such as monetary and fiscal policies, climate change, and equity and growth. Additionally, 25 country case studies were commissioned to explore the dynamics of growth and change in the context of specific countries.

Working papers in this series were presented and reviewed at Commission workshops, which were held in 2007-08 in Washington, D.C., New York City, and New Haven, Connecticut. Each paper benefited from comments by workshop participants, including academics, policy makers, development practitioners, representatives of bilateral and multilateral institutions, and Commission members.

The working papers, and all thematic papers and case studies written as contributions to the work of the Commission, were made possible by support from the Australian Agency for International Development (AusAID), the Dutch Ministry of Foreign Affairs, the Swedish International Development Cooperation Agency (SIDA), the U.K. Department of International Development (DFID), the William and Flora Hewlett Foundation, and the World Bank Group.

The working paper series was produced under the general guidance of Mike Spence and Danny Leipziger, Chair and Vice Chair of the Commission, and the Commission's Secretariat, which is based in the Poverty Reduction and Economic Management Network of the World Bank. Papers in this series represent the independent view of the authors. 


\section{Acknowledgments}

This is a revised version of the paper prepared for the Country Case Studies Workshop organized by the Commission on Growth and Development (Washington DC, April 12-14, 2007). We would like to thank our discussants Homi Kharas and Martin Rama, and Zafer Mustafaoğlu and other workshop participants, for their very helpful comments and suggestions. 


\begin{abstract}
This paper provides an extensive case study of the Turkish automotive and the consumer electronics industries. Despite a macroeconomic environment that inhibits investment and growth, both industries have achieved remarkable output and productivity growth since the early 1990s. Although there are similarities between the performances of the two industries, there are significant differences between their structures, links with domestic suppliers, technological orientation, and modes of integration with the global economy. The automobile industry is dominated by multinational companies, has a strong domestic supplier base, and has seized the opportunities opened up by the Customs Union by investing in new product and process technology and learning. The consumer electronics industry is dominated by a few, large, domestic firms, and has become competitive in the European market thanks to its geographical proximity, productive domestic labor, and focus on a protected and technologically mature segment of the market, which also helps explain the recent decline in industry's fortunes. These industries could have performed even better had more responsive macroeconomic policies been adopted. It is certain that governments could be more responsive only if far-reaching political/institutional reforms are undertaken by changing the constitution and current political party and election laws in order to establish public control over the political elites.
\end{abstract}





\section{Contents}







1. Introduction ............................................................................................ 1

2. Background: Macroeconomic Policies and Performance ....................................2



4. Macroeconomic Policies and Sectoral Performance............................................. 34

5. Sustainability, Institutional Change, and Political Economy of Reform .............40









\title{
Integration with the
}

\section{Global Economy: The Case of Turkish Automobile and Consumer Electronics Industries}

\author{
Erol Taymaz \\ Kamil Yilmaz ${ }^{1}$
}

\section{Introduction}

Why do growth rates differ? This is one of the fundamental questions that have raised intense debate among economists, policy makers, and ordinary citizens for decades if not centuries. Although there is no consensus among economists on explaining growth rate differentials across regions/nations/countries, recent theoretical and empirical studies emphasize the critical role of institutions, the macroeconomic environment, and (macroeconomic) policies.

This paper aims to contribute to the extensive study of the World Bank Commission on Growth and Development by providing a case study of the automotive and the consumer electronics industries in Turkey. These industries are selected from Turkey because they have achieved a remarkable growth in output, productivity, and exports in the last decade against all odds. We attempt to uncover how these industries have performed so well, especially in international markets, and what role macroeconomic policies have played in their success.

The paper is organized as follows. Section 2 summarizes macroeconomic problems, policies, and performance in the long term. After a brief look at the four periods of growth and decline since 1923, macroeconomic policies adopted since 1980 are discussed in detail to provide the background information. Section 3 focuses on the quantitative measures of industrial performance, and provides the data on production, productivity, exports and vertical integration, and profitability for Turkish automobile and consumer electronics industries. The factors behind the performance of these two industries and the role of macroeconomic policies, with a special emphasis on the effects of the Customs Union with the European Union in 1996, are discussed in Section 4. Section 5

\footnotetext{
${ }^{1}$ Erol Taymaz is Associate Professor at the Department of Economics, Middle East Technical University, Ankara, Turkey. Kamil Yilmaz is Associate Professor at the Department of Economics, Koc University, Istanbul, Turkey.
} 
introduces the issue of sustainability and its preconditions, namely the need for political reform. Section 6 summarizes the main findings of the study.

\section{Background: Macroeconomic Policies and Performance}

\subsection{Long-Term Growth Patterns in the Turkish Economy}

Even a cursory look at the patterns of economic growth and economic policies in Turkey reveals that there are four distinct periods of economic growth since the establishment of the Turkish Republic in 1923 (see figure 1). ${ }^{2}$ The first period from 1923 until the Second World War is marked with high but widely fluctuating growth rates that reflect economic conditions of that era (the dominance of agricultural production, the lack of any industry, and the recession in the world economy in the early 1930s). The thrust of economic policy was to establish main industries (textile, food, chemicals, and light engineering) by the state. Because of the initial low level of income, the economy achieved substantial growth rates in this period.

The second period from the Second World War to 1960 is the period of transition towards a multi-party political system. The first multi-party elections were held in 1946, and the second multi-party elections in 1950 put an end to

Figure 1: GDP Per Capita Growth Rates in Turkey, 1926-2005 (5-year moving averages)



Source: Turkstat.

\footnotetext{
${ }^{2}$ Figure 1 depicts 5-year moving average values for annual rates of real GDP growth in Turkey. The forecasted value for 2007 is used in calculating the average for 2005.
} 
three decades of rule by the Republican People's Party. The new government achieved rapid growth in the first half of 1950s, but this period was ended by a military coup in May 1960, following the widespread discontent due to the corruption allegations, the government's tendency towards authoritarianism, and slow economic growth in the second half of 1950s.

The third period from 1960 to 1980 is characterized by a new (more democratic) constitution and a new set of institutions. The new 1961 constitution envisaged (indicative) planning as an important tool for economic development and instigated the State Planning Organization in charge of preparing five-year development plans covering all aspects of economic development. Turkey adopted import substitution industrialization (ISI) strategy in the 1960s and 1970s, and achieved remarkably high and relatively stable growth rates in these decades. The state played an active role in developing a number of industries that produce intermediate products and (especially in the 1970s) machinery and equipment through state-owned enterprises (SOEs). The share of SOEs in manufacturing employment, and value added exceeded 35 and 40 percent, respectively, in the late 1970s. ${ }^{3}$ The SOEs had a dominant position in resourceand scale-intensive industries (paper, chemicals, cement, iron and steel, certain types of machinery and equipment) and produced more than half of the value added of these sectors.

As in many other countries that adopted ISI, Turkey was faced with a serious balance of payment crisis in the late 1970s as a result of rapid increase in the cost of oil imports and increasing import needs during the process of capital deepening. The balance of payment problems slowed down economic growth, and caused even a decline in GDP in 1979 and 1980. The period of ISI was ended by another military coup in 1980.

Turkey adopted export-oriented "industrialization" (EOI) policies after 1980. A wide range of liberalization programs were implemented in the 1980s: The foreign trade regime was liberalized to a large extent in the 1980s, which was followed by full capital account liberalization in 1989. Exports were encouraged by various means (more than 100 percent devaluation of the Turkish Lira in 1980, generous export subsidies throughout the 1980s, and decreasing real wages until 1988). Labor- and resource-intensive sectors were the first to respond to these measures, and total volume of exports (in U.S. dollars) increased more than fourfold from 1980 to 1989. Economic growth rates increased in the 1980s thanks to the export boom and easing balance of payments problems, but the macroeconomic environment deteriorated sharply in the 1990s and the economy was trapped into rising boom and bust cycles. These cycles finally ended with a devastating economic crisis in 2001 (for an assessment of the industrialization experience since 1960, see Şenses and Taymaz, 2003).

${ }^{3}$ The data refers to all SOEs and private establishments employing 10 or more workers. 
The Turkish economy once again achieved historically high growth rates after 2001. GDP grew at high rates for five years in a row since 2001 (the average annual growth rate of GDP reached 7 percent) without any sign of reversal in the growth rate in 2007. Exports increased at phenomenal rates during and after the crisis in 2001: the average annual growth rate of the value of exports (in U.S. dollars) was about 25 percent in the period 2001-06. Two sectors, automobiles and consumer electronics, were among the leading sectors behind the export boom. Automobile exports (including parts and components) increased at 45 percent per year and the growth rate of consumer electronics exports exceeded 30 percent per year since 2001. In the following sections of the paper, macroeconomic policies since the 1980s and the evolution of automobile and consumer electronics industries will be examined in detail to shed light on the factors behind their export performance.

\subsection{Macroeconomic Policies and Performance, 1980-2001}

Turkey followed an inward-looking, import-substituting development strategy during the 1960s and 1970s. Although this strategy worked well throughout the 1960s, it proved impossible to follow in the wake of oil price hikes in 1974 and 1979. After the first oil price shock the government decided not to reflect the international oil price hikes to the domestic market. As a result, the demand for gasoline continued to be strong and the trade deficit soared. The budget deficit also soared thanks to the government's decision to pay most of the oil import bill itself. At the same time, Turkey had gone through the worst political instability in its history. These developments led to the balance of payments crisis of 1979 and a jump in the inflation rate to 64 percent.

The first serious attempt to get inflation under control was announced on January 24, 1980. The stabilization package, which contained a 70 percent devaluation of the Turkish lira, cut government expenditures and substantial increased government-controlled prices, including that of gasoline. The result was a jump in inflation close to 100 percent (see figure 2). On January 24, 1980, a date generally considered as the beginning of a new economic era, a comprehensive IMF-backed stabilization program was launched following a major currency crisis. The immediate objective of the program was to stabilize the economy by improving the balance of payments and containing inflation. The long-term goal, however, was much more ambitious: to change the structure of the economy fundamentally.

Another important objective of the program was to remove the dominance of the state in key industries and in banking, and to minimize the state's intervention with the pricing and resource allocation processes of the market economy. In order to accomplish the external adjustment, export-oriented growth became the key policy objective and the government used export subsidies to promote exports. Starting from 1984, export-oriented policies had later been coupled with a gradual reduction in tariffs and nontariff barriers, and 
finally culminated in the Customs Union (CU) with the European Union (EU) in 1996. As part of the efforts to increase exports, from 1980 to 1988 the government allowed the Turkish lira to depreciate in real terms by 36 percent (figure 3 ).

Figure 2. Consumer Price Inflation, 1980-2006 (end of year)



Source: Turkstat.

Figure 3. Real Effective Exchange Rate (CPI-based, annual average)



Source: Turkstat. 
Figure 4. GNP Growth Rates (1980-2006, percent per year)



Source: Turkstat.

Although a lot had been achieved until 1986, one thing that was conspicuously lacking was the control over the fiscal deficit. Despite favorable domestic and international circumstances, neither the military government of 1980-83 nor the Özal government of 1983-87 was able to cut the budget deficit on a permanent basis. Actually, there were some positive signs in the first few years of the decade. As a result of the pressure on real wages and cuts in politically motivated government expenditures, the public sector borrowing requirement was reduced from 10 percent of GNP in 1980 to 5.4 percent in 1981. Inflation was brought down from 107 percent in 1980 to 37 percent in 1981 and 28 percent in 1982. However, 28 percent has since proven to be the lower limit of annual inflation in Turkey until recently (figure 2)

The reorientation of the Turkish economy had its effects in the 1980s. From 1981 to 1987 the economy attained annual growth rates above 4 percent per year. However, this initial successful phase of reforms could not be sustained. The external adjustment of the economy could be sustained over the long run and there were real problems emerging in the internal adjustment process. With the free general elections of 1987, the full competition in politics restarted. In the wake of intensified political competition, populist policies were discovered. During the 1987-2001 era, economic performance was very erratic. Strong growth performance for one or two years was followed by a sharp decline to negative territory (figure 4). As a result, Turkey achieved only an average 2 percent growth rate in per capita GDP over this period.

In the second half of 1980s, the government issued decrees to remove some of the barriers to foreign direct investment (FDI). As a result, the FDI inflows increased above the dismally low levels of the period before. Whereas average annual FDI inflows between 1981 and 1987 were only US\$110 million, after the government decree to promote FDI was put into effect in 1986, FDI inflows 
increased from US\$354 million in 1988, to US\$662 million and US\$684 million in 1989 and 1990, respectively.

Trade and financial liberalization efforts of the decade finally culminated in the opening of the capital account in August 1989. Although the decision to open the capital account can be viewed as a step in the right direction, at the time it was criticized as an immature decision. Reforms to liberalize financial markets had already been undertaken at the time, but an effective regulation system for the financial sector was not put in place. Another criticism held that the government's decision to liberalize the capital account in 1989 was mostly driven by its desperate need to finance increasing budget deficits. As the borrowing through the domestic market reached its limits the interest rates started to increase. At a time of intense political competition, the government ruled out any attempts to tighten the fiscal policy. The capital account liberalization was an immediate solution for the government at the time.

With the decision to liberalize the capital account, government decided to move away from an exchange rate policy that was geared to promote exports, toward one that viewed the exchange rate as an implicit anchor for domestic prices. This new function for the exchange rate was also enforced by the portfolio capital inflows that led to real appreciation in the Turkish lira. From 1988 to 1993, the lira appreciated by 18 percent, before a maxi devaluation during the 1994 crisis (figure 3).

Turkey successfully liberalized its foreign trade regime, removed price ceilings on goods and services and other distortions in product markets, and deregulated its financial sector long before many Latin American and East European countries. However, the country was not able to attain macroeconomic stability.

The inflation varied widely: From close to 100 percent in 1980 it declined to 34.6 percent in 1986; it increased over time and reached 140 percent during the economic crisis of 1994. As can be seen in figures 1 and 4, output growth also has been volatile with periods of rapid growth followed by sharp contractions. As the Turkish lira lost its store of value function, foreign exchange deposits became increasingly important, at times representing almost 50 percent more than the domestic money supply measure M2 (during the 1994 economic crisis and after September 11, 2001).

The reason for the volatile macroeconomic environment and high inflation has been the inability of successive governments to deal with the underlying causes of poor public finances. During the 1980s government reform efforts focused on external adjustment. The internal fiscal adjustment that was necessary to reduce inflation permanently was never achieved nor seriously attempted. Despite early fiscal successes following a stabilization program, public sector deficits soon resumed their secular climb. Fiscal dynamics drove the monetary and exchange rate policy mix and set the key parameters for evolution of the economy and the functioning of financial markets. 
The capital account was opened untimely in 1989 under unstable macroeconomic conditions. Under the open capital account, the Central Bank adopted a managed exchange rate policy to control inflation. When there is no adjustment of fiscal balances, a managed float can be instrumental in keeping the inflation under control only for a while. Eventually, the pegged exchange rate policy was doomed to fail. Appreciated domestic currency increases the vulnerability of the economy to external shocks and domestic policy mistakes. This process explains the crises of 1994 and 2001 in Turkey.

The economic crisis of 1994 did not alter the course of fiscal policies. Domestic and foreign investors were willing to finance the fiscal deficits as long as the Treasury was willing to offer higher and higher yields. Meanwhile, the government made full use of the state-owned banks to finance the fiscal deficit through short-term loans to the Treasury. It seemed at the time that the system would work fine as long as the short-term capital inflows continued, but that was not the case. Chronic fiscal deficits coupled with high real interest rates led to the unsustainable debt dynamics. Public sector borrowing requirements increased from 5 percent of GNP in 1995 to as high as 15.6 percent in 1999 and the ex post real interest rates on bonds and T-bills were above 20 percent, reaching as high as 36 percent (see table 1 ).

Both domestic and external shocks in the final year of the 1990s exposed the impossibility of sustaining macroeconomic policies. The Turkish economy was directly affected by repercussions from the Russian debt crisis of 1998. As Turkey also suffered from chronic fiscal imbalances, it experienced an outflow of shortterm portfolio investments following the crisis in August 1998. Starting in September 1998, the economy slowed down gradually. The economic downturn intensified throughout 1999, especially after the devastating earthquake in the Marmara region on August 17, 1999.

Following the earthquake, the government was convinced of the need for a stabilization program. At the end of 1999, the government and the IMF agreed upon an exchange rate-based disinflation program that went into effect in 2000. The program entailed tight fiscal policy along with a crawling peg exchange rate regime under which the exchange rate was announced in advance in order to anchor inflation expectations. The exchange rate-based stabilization was expected to bring real interest rates down and ensure the sustainability of the already high public debt. Another important component of the program was banking sector reform, entailing the establishment of an effective banking sector regulatory body. 


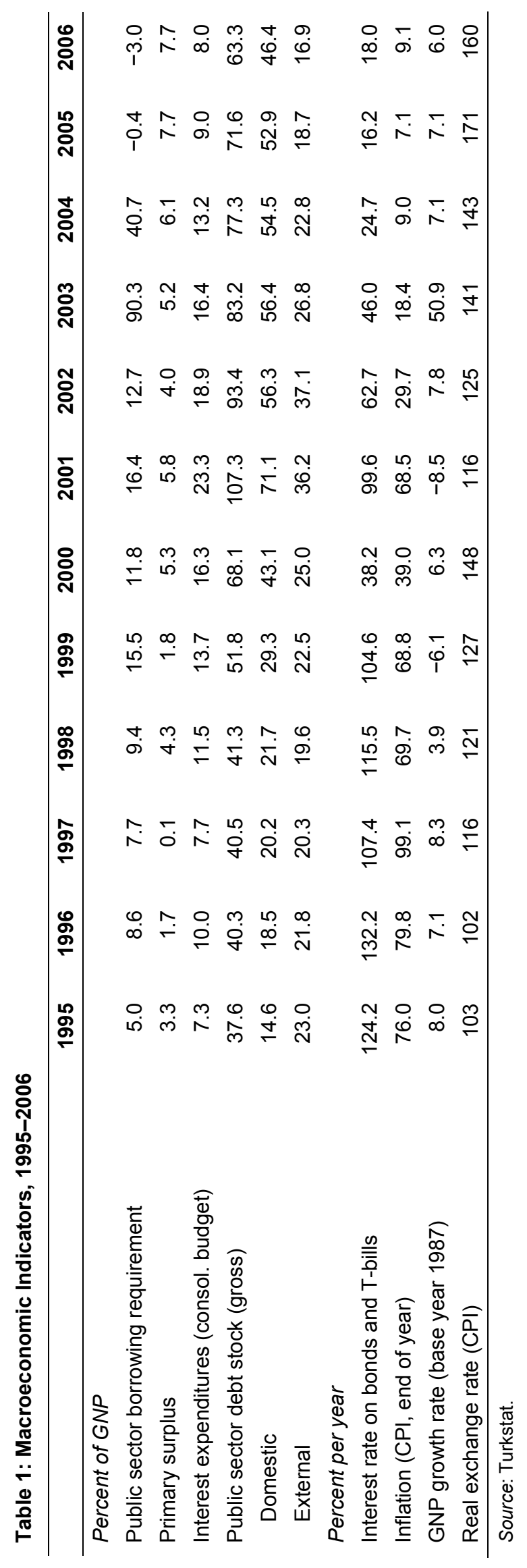


Initially, the program had the desired impact on interest rates. From above 100 percent in 1999, the T-bill rate fell below 40 percent in the first half of 2000 and declined further below to 35 percent in the second half of 2000. Inflation, on the other hand, declined gradually from 63 percent in December 1999 to 33 percent in December 2000. However, not unlike other countries that had implemented the exchange rate-based programs in the past, in February 2001 Turkey witnessed a dramatic collapse of the disinflation program and experienced the worst economic crisis in its history with a quasi-meltdown in financial markets.

Even though the crisis was triggered by a confrontation between the president and the prime minister in a top-level meeting, there were several other contributing factors. To start with, there were problems with the initial design of the program. Reached as a compromise between the government and the IMF, the crawling peg regime could not bring about a rapid decline in inflationary expectations and hence the actual inflation rate. The ensuing rapid overvaluation of the lira proved to be fatal in the presence of a financial system with many lossmaking public and private banks. In the weak and unregulated Turkish financial system, the crawling peg regime further strengthened the local banks' appetite for external borrowing and increased their vulnerability to a rapid depreciation of the lira. The inability of the government to implement the structural measures entailed in the disinflation program was also another key factor that led to the crisis. At the time there was a coalition government in power with little coordination and effective governance. In the first three quarters of 2000, the government gave in to the pressure from bank owners and delayed the establishment of the Banking Regulation and Supervisory Agency. This delay further alarmed already worried foreign investors and convinced some to move their portfolio investments outside the country.

An important milestone in the 1990s was the formation of the CU between Turkey and the EU in 1996. The Turkish economy's performance after joining the CU provides insights for its future performance as it integrates more with the EU economies. Therefore, the effect of the CU on Turkish economy is analyzed briefly here, although it is not part of the macroeconomic policy framework.

Traditionally, Turkey has had strong trade relations with Europe. Between 1999 and 2003, trade with the EU-25 accounted for 53 percent of Turkey's exports and 51 percent of imports. Defining Europe to include countries that became members in 2004, and Bulgaria and Romania that joined in 2007, Europe's share of Turkish exports and imports in 2004 was 59 percent and 53 percent, respectively. By end-2005, the rapid increase in imports from China in the 2000s had reduced Europe's share in imports to 49 percent. However, the EU continues to be the most important trade partner for Turkey.

The overall impact of the CU on the Turkish economy has been positive, but less than its full potential. First, there was a small decline in import tax revenues 
as Turkey lowered tariffs for imports from the EU. ${ }^{4}$ Import tariff revenues fell from 2.8 percent of total tax revenues in 1995 to 1.1 percent average over the period 2001-05. The decline in tax revenues, however, is too small to be blamed for the large budget deficits.

Increased competition in the form of higher imports from the EU forced productivity improvements in the manufacturing industry. Some of these sectors such as automotive, durable home appliances, electrical machinery, and equipment had continued to receive protection behind high tariff barriers despite the import liberalization process that started a decade ago. Compared to other sectors, productivity growth was higher in import-competing sectors.

The track record of the Turkish manufacturing industry in response to the $\mathrm{CU}$ has been better than expected, especially when one considers that Turkey received very little financial support from the EU to help ease the adjustment burden. In Taymaz and Yilmaz (2007), we showed that even though the total factor productivity in the manufacturing industry did not increase much after the $\mathrm{CU}$, the productivity in those sectors that experienced significant increases in important penetration rates increased substantially.

The CU agreement with the EU did not have much impact on Turkish exports in the first five years (for growth rates of exports and imports, see figure 5). The EU had already removed tariffs on imports from Turkey long before the CU went into effect. In addition, despite the CU, the EU continued to reserve the right to impose antidumping duties on Turkish exports to the EU as well as keeping technical (regulation) barriers. Coupled with the appreciation of the lira, it is therefore not surprising that Turkish exports did not surge to the EU countries immediately after the CU.

The impact of the CU on Turkish exports was realized with a long delay, only after the 2001 crisis. The depreciation of the lira and the contraction in domestic demand that followed the economic crisis of February 2001 forced domestic producers to search for export markets. Export revenues increased by only 12.6 percent in 2001. Exports continued to grow even after the domestic market resumed growth in 2002 and 2003 at a rate higher than the period prior to the crisis. Exports grew by 15 percent in 2002, 31 and 34 percent in 2003 and 2004, and by 16 percent in 2005 and 2006. Better-than-expected export performance in 2002 and 2003 was achieved despite a 25 percent real appreciation, and even nominal appreciation, of the Turkish lira during this period. This remarkable export performance is in part due to the newly acquired competitiveness of the Turkish manufacturing industries that was forced by the increased competition after Turkey joined the CU.

\footnotetext{
4 According to calculations reported in Togan (1997), the unweighted average tariff for the manufacturing industry decreased from 13.5 percent in 1995 to 3.6 percent in 1996.
} 
Figure 5: Growth Rates of Manufacturing Exports and Imports (1981-2006)



Source: Turkstat.

The major disappointment with the CU has been the lack of any change in FDI flows to Turkey. It was expected that FDI inflows (especially those from Europe) to Turkey would increase substantially following the CU agreement. Turkish governments had hoped that multinational companies would have taken advantage of the country's geographical location, low-cost and disciplined labor, and long experience with a market economy. Unfortunately, this expectation did not come true. Four years after the CU, in 2000 Turkey attracted US\$15 of FDI per capita. The same year Poland attracted US\$105, Romania US\$50, Brazil US\$96, Algeria US\$32, and Ireland US $\$ 4,750$.

Unlike the CU, the EU's decision at the end of 2004 to start accession talks with Turkey had substantial impact on FDI inflows to Turkey. As a result of the structural reforms implemented since 2001, this time around the macroeconomic policies and structural reforms have created an investment climate that is much more suitable for FDI inflows. Experience with the CU so far demonstrates the resiliency and adaptability of Turkish manufacturing industries to rapidly changing conditions during a period with almost no net FDI.

\subsection{Macroeconomic Policies and Performance since 2001}

The 2001 crisis was the worst economic crisis Turkey had ever experienced since its foundation in 1923. As a result of the crisis, GNP dropped by 9.5 percent in 2001. A short period of turmoil in financial markets had a severe toll on public finances. The government debt increased by more than 40 percent of GDP by the end of the year. As the lira depreciated by 30 percent in six months, inflation picked up very rapidly to reach 70 percent by the end of the year. 
Figure 6: Budget Balance in Turkey (1990-2006, percent of GDP)



A huge IMF bailout package was prepared with the conditionality of the implementation of a stabilization program. Kemal Derviş of the World Bank was invited by the Prime Minister Ecevit to be in charge of the economic recovery program. Derviş played a pivotal role to ensure the success of the post-crisis recovery efforts. The program was eventually put in place to address the two bottlenecks of the economy: namely, to ensure the sustainability of the government debt burden through a primary surplus of 6.5 percent of GNP over a couple of years, and to rescue the banking system. The banking sector reform was implemented without any further delay.

More than a year after the crisis, the coalition government collapsed in July 2002 and the country held yet another early general election in November 2002. In the November 2002 elections, a recently founded party, AKP (Justice and Development Party) received 34 percent of the votes and formed a single party government. Initially, the government sent populist messages to the public hoping to obtain a large financial aid package from the United States in exchange for the opening of the northern front in Iraq through Turkish border. However, as the Turkish parliament rejected the motion to open a corridor for U.S. forces, the government had to take drastic measures. It declared that it would stick to the primary surplus of 6.5 percent of GNP target of the IMF-supported program. The AKP government succeeded in achieving the 6.5 percent of GNP target for 2002-06 (figure 6). As foreseen in the "Transition to a Strong Economy" program prepared by Kemal Derviş and his team, the persistent primary surplus over the period led to a gradual decline in the overall fiscal deficit and the public sector borrowing requirement (see figure 6 and table 1). As the public sector's demand 
for loanable funds declined over time so did the nominal and real interest rates. The nominal interest rates declined from 60 percent in 2002 to less than 20 percent in early 2005. The real interest rates, on the other hand, declined from 25 percent per year during 2002, to close to 10 percent in mid-2003 (figure 7).

The economic performance of 2002-06 was not only a result of the successful implementation of macroeconomic reforms. In addition, the prevalence of a very benign international environment for emerging markets since 2003 helped Turkey grow faster than the domestic savings would have allowed. Due to the easy monetary policy and the resulting low interest rates in the United States and other industrial countries, financial capital has been consistently flowing to emerging markets. In addition, high and robust growth rates attained by China and India along with the ever-growing United States helped pull the world economy along. Although the international portfolio flows to Turkey over the 2002-05 period and the ensuing overvaluation of the lira helped the inflation stabilization efforts, a reversal would lead to a jump in the expected and actual inflation. Developments in international financial markets in May-June 2006 showed how closely the success of the inflation stabilization program and Turkey's overall macroeconomic balance is linked to the direction of international portfolio capital flows. Turkey will continue to feel the positive and negative impact of international financial flows and the authorities should be better prepared to manage the short-lived turbulences in international financial markets. It remains to be seen, however, whether Turkish economy can sustain its growth by largely relying on capital flows from abroad.

Figure 7. Nominal and Real Rates of Interest (January 2002-May 2007)



Source: Undersecretariat of Treasury. 
Following the 2001 crisis, Turkey adopted the flexible exchange rate regime. Subsequently the Central Bank of Turkey (CBT) implicitly followed inflation targeting as the main monetary policy framework. At the beginning of 2006, the Central Bank switched to explicit inflation targeting. Beginning in 2002, the flow of portfolio capital to emerging markets helped policy makers in the implementation of fiscal and monetary policy measures. The CPI-based reel effective exchange rate index increased from 116 at the end of 2001 to 171 at the end of 2005. However, following the U.S. Federal Reserve's decision to raise the federal funds rate further in May 2006, there was a huge flow of international portfolio capital from emerging markets to industrial countries. The reversal in the direction of portfolio flows had a substantial impact on Turkish financial markets. In real terms, the Turkish lira lost about 20 percent against the U.S. dollar and the euro in May and June 2006. As a result, the real effective exchange rate dropped to 142 . The situation could only be stabilized after a 4.25 percent hike in the overnight interest rate by Turkey's Central Bank in two consecutive meetings to 17.5 percent. In the meantime, the deprecation of new lira against the U.S. dollar and the euro fed into inflation. At the end of 2006 the inflation rate was 9.7 percent, much higher than the 5 percent target for the year.

Banking sector reforms, the switch to a flexible exchange rate regime, and fiscal discipline started paying off. After six years of tight fiscal policy, the gross public sector debt was brought down from its peak of 107 percent of GDP at the end of 2001 to 63 percent at the end of 2006 (table 1). When one looks at the net public sector debt to GDP ratio, this figure declined to 45 percent by the end of 2006. Moreover, the banking system went through a period of recovery after injection of US $\$ 40$ billion dollars to recapitalize private and public banks. Five years after the 2001 crisis, Turkish banking system is in much better shape. As a result, following the EU's December 2004 decision to initiate membership negotiations with Turkey, multinational banks' interest in Turkish banks increased substantially. As of June 2007, the share of foreign capital in the banking system reached 42 percent.

In addition to the banking sector, foreign investors showed keen interest in the privatization of large public enterprises. The foreign interest in the financial sector and the privatized companies together resulted in the sudden jump of FDI inflows from US $\$ 2.8$ billion in 2004 to US $\$ 10$ billion in 2005, US $\$ 20$ billion in 2006, and US\$22.2 billion in 2007. Although the FDI inflows played a critical role in financing a significant portion of the current account deficit in 2005-07, there are serious signs that large FDI inflows may not continue beyond 2008. More than 90 percent of FDI inflows in 2005-07 were in the form of mergers and acquisitions and mostly targeted companies in the service sectors. Turkey has been unable to attract multinational corporations as an alternative destination for large-scale export-oriented greenfield investments.

Seven years after the 2001 economic crisis Turkey is still a vulnerable economy. The country still has high public and external debt ratios compared to 
other countries. In addition, despite the flexible exchange rate regime, the current account deficit increased rapidly after 2001, reaching 8 percent of GNP at the end of 2006 (see figure 8). One reason for the rapid increase in the current account deficit was the oil price hikes since 2004. Once corrected for the increased crude oil prices the current account deficit is not very large. If the oil prices stayed around US $\$ 25$ per barrel since 2003, the current account deficit would have stayed around 4 percent of GNP since 2004. Even if the imports increase can be accounted for by the oil price hikes since 2003, the actual current account deficit could have been under control if TL had not appreciated substantially over the period. One of the challenges for the future will therefore be to adopt policies that would make the economy less vulnerable to unexpected shocks.

Another important challenge for the future is to insure that the country grows close to its full potential. Since 2002 Turkey has grown by an average of 7.2 percent per year. Although this is a commendable achievement at par with East Asian countries, the problem lies with the downward trend in the growth rates. The growth rate declined to 4.5 percent per year in 2007. Clearly, Turkey is falling behind its desired growth rate.

Figure 8: Current Account Deficit (CAD) and the Impact of the Recent Hike in Oil Prices

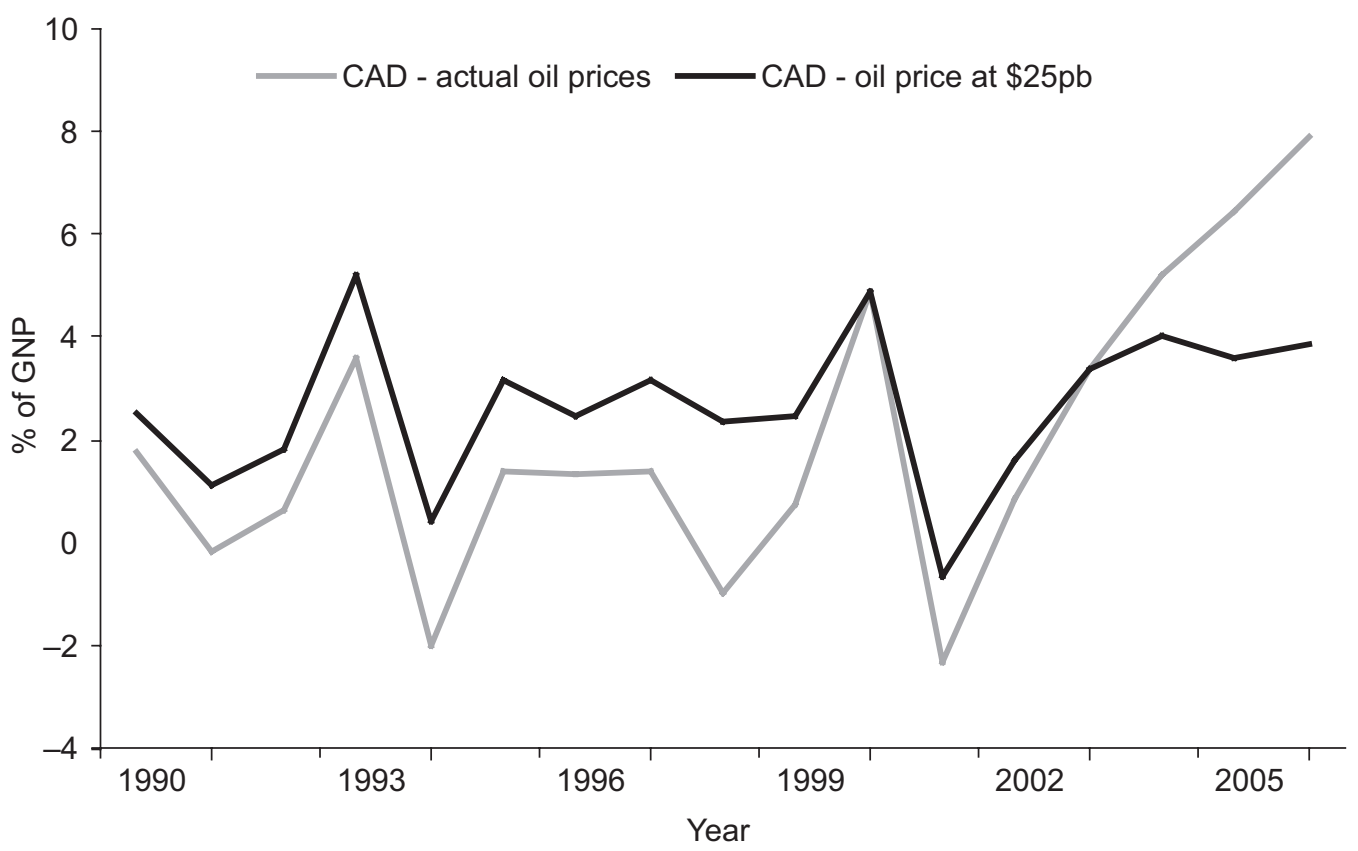

Source: Turkstat. 
Turkey needs to grow above 7 percent per year (against a population growth of around 1.5 percent) to close the huge income gap with the EU. In 2005, GDP per capita in Turkey at purchasing power parity was only 28 percent of the average GDP per capita in EU-25 countries. Without moving its GDP per capita close to 40 percent of the EU-25 average, it will be difficult to convince the EU public that Turkey's eventual membership will not be a big burden on the EU.

Perhaps the surge in unemployment was the longest-lasting impact of the 2001 crisis. The unemployment rate increased from 6.5 percent in 2000 to 8.4 percent in 2001 before reaching to 10. percent in 2003 (see figure 9). Since then Turkish economy has created a rather respectable 1.2 million new jobs, but this was not sufficient to bring the unemployment rate down to pre-crisis levels. As of the end of 2006 unemployment rate stood at 9.9 percent. The unemployment rate could not be brought down despite 400,000 new jobs created every year, because the agriculture sector has shed 2 million jobs since 2001 and 1.1 million jobs since 2003. When we include those discouraged workers as part of the unemployed pool, the expanded definition of unemployment is close to 17 percent as of the end of 2006 (figure 9). All these numbers related to the labor market indicate the urgent need for micro reforms that will reduce the cost of creating new jobs.

Finally, inflation is another area where there is much left to be done. At the moment inflation seems stuck at high single digits. Given the possibility of external as well as domestic economic and political shocks, it will prove quite difficult to achieve the low inflation target of 4 percent and below.

Challenges facing the Turkish economy have to be confronted by further reforms. Reforms towards openness and financial soundness have to be combined with micro "supply-side" reforms. The structural reforms that had started in earnest after the 2001 economic crisis should be deepened and widened. Banking sector, social security, regulatory, and fiscal reforms that have been implemented so far need to be further deepened. In addition, those structural reforms that had been delayed so far have to be implemented as soon as possible. The most important step is tax reform and containment of the shadow economy. Already high indirect and direct tax rates have to be brought down and tax collection has to be enforced vigorously. Implementation of tax reforms will require a complete overhaul of the tax administration. Without tax reform it will not be possible to lower the cost of labor, especially the tax burden on minimum wages. In addition, institutional and political reforms that ensure the smooth functioning of the market economy need to be enacted. We will discuss political reforms in Section 5. 
Figure 9: Labor Force and Employment (2000-06)

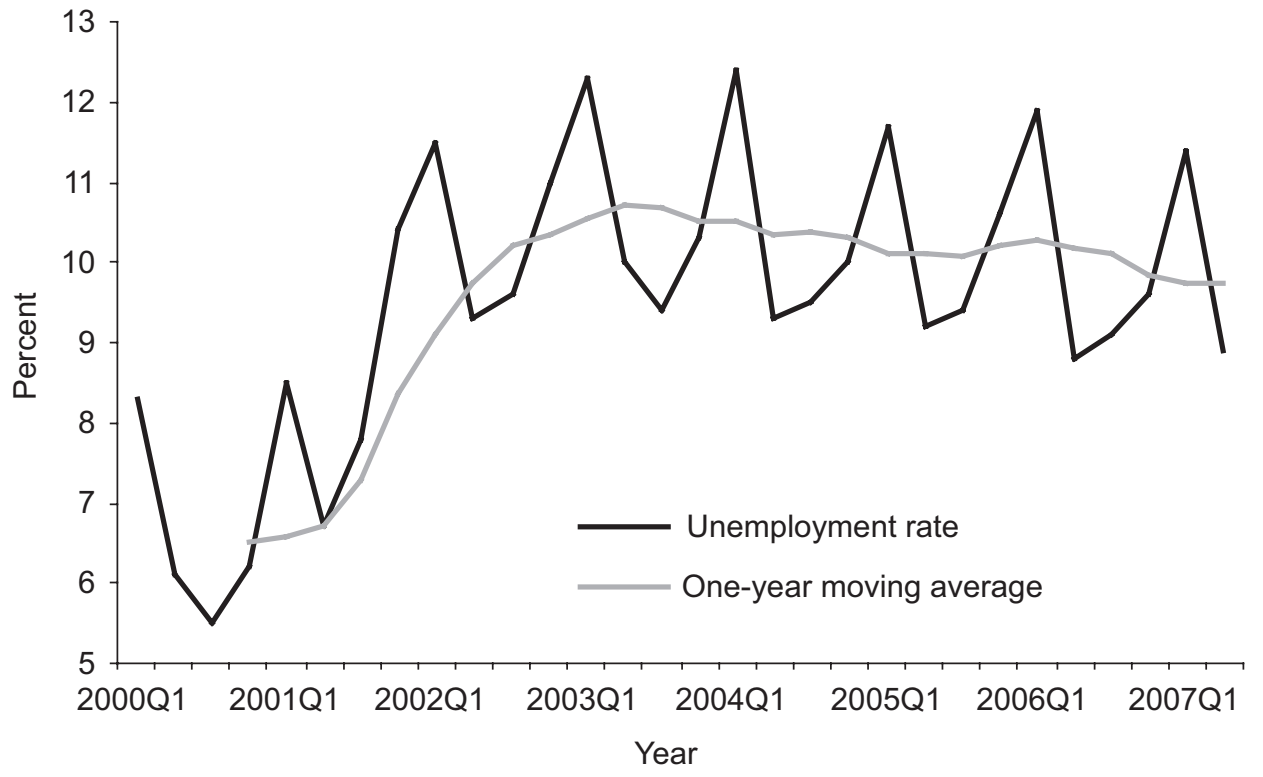

\begin{tabular}{lrrrrrrr}
\hline (in thousands) & $\mathbf{2 0 0 0}$ & $\mathbf{2 0 0 1}$ & $\mathbf{2 0 0 2}$ & $\mathbf{2 0 0 3}$ & $\mathbf{2 0 0 4}$ & $\mathbf{2 0 0 5}$ & $\mathbf{2 0 0 6}$ \\
\hline Non-institutional population & 66,187 & 67,296 & 68,393 & 69,479 & 70,556 & 71,611 & 72,606 \\
Population 15 years of age and over & 46,211 & 47,158 & 48,041 & 48,913 & 49,906 & 50,826 & 51,668 \\
Labor Force & 23,078 & 23,491 & 23,818 & 23,641 & 24,290 & 24,565 & 24,776 \\
Employed & 21,581 & 21,524 & 21,354 & 21,148 & 21,792 & 22,046 & 22,330 \\
$\quad$ Agriculture & 7,769 & 8,089 & 7,458 & 7,165 & 7,400 & 6,493 & 6,088 \\
$\quad$ Industry & 3,810 & 3,774 & 3,954 & 3,846 & 3,987 & 4,284 & 4,407 \\
$\quad$ Construction & 1,364 & 1,110 & 958 & 965 & 1,030 & 1,173 & 1,267 \\
$\quad$ Service & 8,637 & 8,551 & 8,984 & 9,171 & 9,374 & 10,096 & 10,569 \\
$\quad$ Unemployed & 1,497 & 1,967 & 2,464 & 2,493 & 2,498 & 2,520 & 2,446 \\
Outside the labor force & 23,133 & 23,667 & 24,223 & 25,272 & 25,616 & 26,261 & 26,892 \\
$\quad$ Ready for work, not looking for job ${ }^{\text {a }}$ & 1,139 & 1,060 & 1,020 & 945 & 1,223 & 1,714 & 2,087 \\
Labor force participation rate (\%) & 49.9 & 49.8 & 49.6 & 48.3 & 48.7 & 48.3 & 48.0 \\
Unemployment rate (\%) & 6.5 & 8.4 & 10.3 & 10.5 & 10.3 & 10.3 & 9.9 \\
Non-farm unemployment rate (\%) & 9.3 & 12.4 & 14.5 & 13.8 & 14.3 & 13.6 & 12.6 \\
Expanded unemployment rate (\%) & 10.9 & 12.3 & 14.0 & 14.0 & 14.6 & 16.1 & 16.9 \\
\hline
\end{tabular}

Source: Turkstat.

a. Including those looked for a job but couldn't find in the last 3 months.

\section{Automobile and Consumer Electronics Sectors}

\subsection{Production}

The first automobile assembly plant in Turkey was established in 1960, and a number of joint ventures entered into the market in the late 1960s. Under the ISI policy, the automobile industry in Turkey aimed at satisfying domestic demand, and there were almost no exports until the late 1980s. Domestic production increased until 1976 (total production reached 110 thousands units), but declined 
until 1980 because of supply shortages. There was also an increase in the number of local suppliers in the Marmara region during the 1970s. Production increased steadily after the early 1980s, and as a result of increasing demand and the prospects of the CU with the EU in 1996, the industry expanded its production capacity in the early 1990s.

The economic crisis in 1994 had a disastrous impact on production, which declined by almost 50 percent. In spite of the 1994 crisis, the industry attracted FDI, and new companies (for example, Toyota in 1994, Honda and Hyundai Assan in 1997) or new plants by existing companies (for example, Ford in 2001) expanded the production capacity. Total production gradually increased after the 1994 crisis and exceeded its 1993 level in 2000 partly as a result of increasing exports to the EU countries. The 2001 crisis was a step backward in production (down to the 1994 crisis level), but the industry bounced back very strongly after the crisis and achieved almost four-fold increase in output from 2001 to 2006 (or two-fold increase from 2000, the peak year, to 2006; see figure 10). Exports played an important role in increasing automobile production in the post-crisis period (for a detailed history of the automobile industry in Turkey, see State Planning Organization, 2005).

The information and communication technology (ICT) industries ${ }^{5}$ in Turkey have been relatively underdeveloped, and have had a small share in total manufacturing output. Turkey initiated a comprehensive program to modernize

Figure 10: Industrial Production Index (1980-2006, 1997=100)

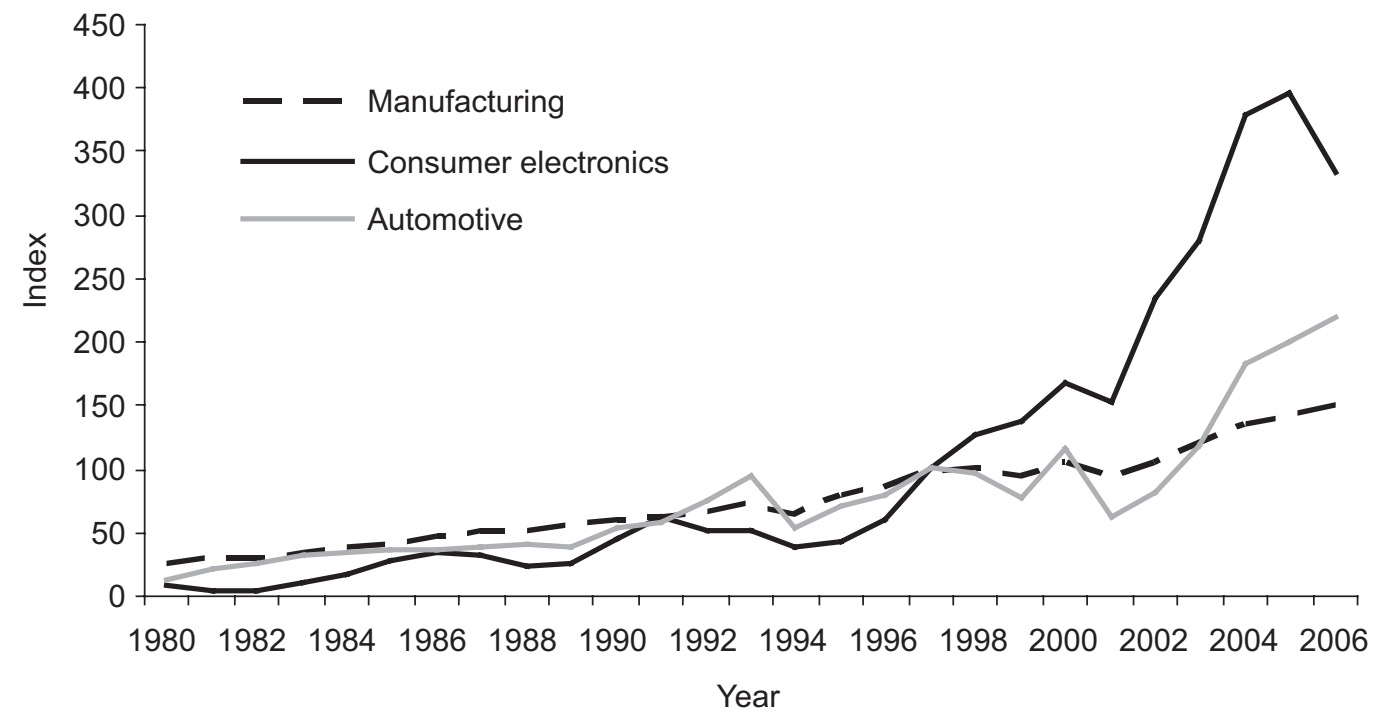

Source: Turkstat.

\footnotetext{
5 The ICT industries refer to office, accounting, and computing machinery (ISIC 3000); electronic valves, tubes, etc. (ISIC 3210); TV/radio transmitters; line communication apparatus (ISIC 3220); and TV/radio receivers and associated goods (ISIC 3230). ISIC codes refer to International Standard Industry Classification, Revision 3.
} 
the ICT infrastructure in the late 1980s, which led to substantial investment in infrastructure and encouraged a number of foreign firms to invest in Turkey. Other segments of the industry (computers, components, and consumer electronics) had moderate growth rates in the 1980s. After years of stagnation and even a slight decline in real output, the consumer electronics sector started to grow very rapidly in the mid-1990s, and achieved almost 10-fold increase in real output in a decade (from 1995 to 2005, see figure 10). Most of the increase in the output of consumer electronics sector in Turkey is accounted for by a rapid increase in the production and exports of color television receivers (see Çakır, 2004). The industry produced 1.8 million color TV receivers in 1995 and production increased to 6.9 million in 1999, to 12.3 million 2002, and to 20.4 million in 2004. However, the production of color TV receivers stagnated (20.7 million units) in 2005 before declining to 18 million in 2006.

The decline in the exports and production of color TV receivers in recent years are directly reflected in the decline of the industry's production index by 16 percent in 2006. The industry's fortunes are further worsened by the fact that it is losing market share not only in the EU market but also in the domestic market due to rapid switch from tube TV receivers to plasma and LCD TV receivers. In the first four months of 2007 the industry's production index further slipped by another 33 percent compared to the 2006 level.

In the late $1990 \mathrm{~s}^{6}$ the ICT and automobile ${ }^{7}$ industries accounted for 7.7 percent of manufacturing value added and 5.4 percent of manufacturing employment (see table 2). Motor vehicles and automobile components sectors have the highest share in value added and employment, followed by TV/radio transmitters and TV/radio receivers (consumer electronics) sectors.

The automobile industry employed about 50,000 people in 2000, and there was a 60 percent increase in the number of production workers through $2006 .{ }^{8}$ When micro and informal firms and suppliers in other sectors are taken into account, the automobile industry is undoubtedly one of the leading sectors (in terms of employment generation and creation of value added) in Turkey.

\footnotetext{
${ }^{6}$ As of writing the final version of this report, the annual data for manufacturing industries for 2002 were not available. The data for manufacturing industries exclude private establishments employing less than 10 people, and those operating in the informal sector.

${ }^{7}$ Hereafter, "automobile industries" refer to motor vehicles (ISIC 3410); automobile bodies, trailers, and semi-trailers (ISIC 3420); and parts/accessories for automobiles (ISIC 3430).

${ }^{8}$ The Annual Survey of Manufacturing Industries conducted by the Turkstat provides basic data for employment, output and value added at the sectoral level. Unfortunately, the latest year for which the data are available is 2001. For the post-2001 period, the Short Term Statistics (STS) collected quarterly by the Turkstat are used to estimate employment and output growth rates. The STS covers only large establishments producing about 90 percent of sectoral value added.
} 
Table 2: Descriptive Statistics on ICT and Automobile Industries in Turkey (1995-2000 averages)

\begin{tabular}{lccccc}
\hline & $\begin{array}{c}\text { Number of } \\
\text { employees } \\
(\mathbf{2 0 0 0 )}\end{array}$ & $\begin{array}{c}\text { Employment } \\
\text { share } \\
\text { (percent) }\end{array}$ & $\begin{array}{c}\text { Value added } \\
\text { share } \\
\text { (percent) }\end{array}$ & $\begin{array}{c}\text { Relative } \\
\text { labor } \\
\text { productivity }\end{array}$ & $\begin{array}{c}\text { Relative } \\
\text { wages }\end{array}$ \\
\hline Computing machinery & 1,186 & 0.06 & 0.08 & 1.11 & 0.92 \\
Electronic components & 1,353 & 0.11 & 0.06 & 0.53 & 0.83 \\
TV/radio transmitters & 5,535 & 0.53 & 1.11 & 2.25 & 2.81 \\
TV and radio receivers & 7,375 & 0.59 & 0.87 & 1.52 & 1.47 \\
Motor vehicles & 28,060 & 2.20 & 4.11 & 1.86 & 1.83 \\
Automobile bodies & 2,762 & 0.28 & 0.17 & 0.59 & 0.81 \\
Automobile components & 18,042 & 1.65 & 1.30 & 0.78 & 1.11 \\
Total (ICT and automobiles) & 64,313 & 5.42 & 7.69 & 1.42 & 1.59 \\
\hline
\end{tabular}

Source: Calculated from UNIDO, Industrial Statistics Database, 2007.

As shown in table 2, the ICT industries are unevenly developed in Turkey. Computing machinery and electronic components sectors are extremely small. These two industries together account for less than 0.2 percent of manufacturing employment and value added. TV/radio transmitters and TV/radio receivers sectors have a larger share (slightly more than 1 percent of employment and 2 percent of value added). As will be shown in Section 3.4, the TV/radio transmitters sector is dominated by large, foreign firms that serve only the domestic market. However, the TV/radio receivers sector is well-integrated with the world markets and exports a substantial part of its output. Therefore, one needs to focus on the consumer electronics sector (or, more specifically, cathode ray tube color television receivers) in analyzing Turkey's integration with the world economy in ICT industries.

\subsection{Productivity}

The pattern of productivity growth in consumer electronics and automobile sectors is very similar to the pattern of output growth. An analysis of the indices of labor productivity ${ }^{9}$ reveals that labor productivity growth rates in consumer electronics and automobiles were at par with that of manufacturing industry. The automobile industry did not increase its labor productivity to a large extent from the early 1990s until the early 2000s, a period dominated by the boom and bust cycles. The negative and detrimental effects of the economic crisis on labor productivity in the automobile industry are seen in 1994, 1999, and 2001. However, labor productivity recovered rapidly after the 2001 crisis and increased two-fold from 2001 to 2006 (figure 11). ${ }^{10}$

\footnotetext{
${ }^{9}$ Labor productivity is defined by valued added per employee.

10 Total factor productivity growth (TFPG) in the automobile industry had a similar trend (see figure 12). Total factor productivity for the 1989-2001 period was calculated using Olley-Pakes. TFPG series were imputed for 2001-06 by using the index for labor productivity.
} 
Figure 11: Industrial Labor Productivity Index (1980-2006, 1997=100)

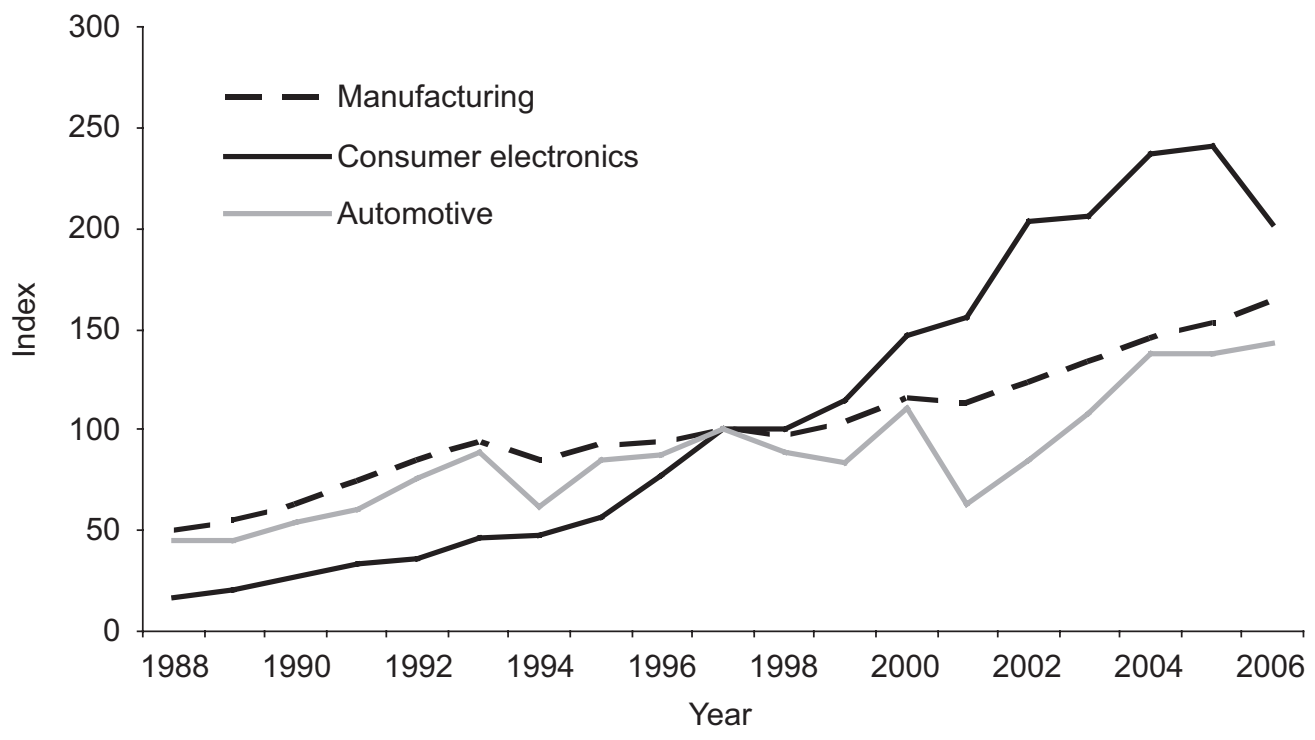

Source: Turkstat.

Figure 12: Total Factor Productivity Index (1989-2006, 1989=1, 2001-06 imputed)



Source: Authors' calculations based on the Olley-Pakes method.

The consumer electronic sector had a steady but slow labor productivity growth in the late 1980s and early 1990s. The increase in total factor productivity (TFP) growth was even lower (see figures 11 and 12). Productivity, especially TFP, started to grow rapidly and continuously after 1995, and average annual growth rate of labor productivity (TFP) reached 15 percent (10 percent) for a decade.

To sum up, the consumer electronics sector have achieved above average growth rates in productivity since the mid-1990s, whereas the automobile industry's productivity growth performance is almost equal to the manufacturing average. However, the level of productivity also is important in 
assessing industrial performance. The data on labor productivity reveal that there are substantial productivity differentials between ICT and automobile final producers and other manufacturing industries. The motor vehicles industry is 86 percent more productive than the manufacturing industry average, whereas the productivity differential reaches 125 percent for TV/radio transmitters and 52 percent for TV/radio receivers. Components producers for ICT and automobiles (electronic components, automobile bodies, and automobile components) are much less productive (about 53,59, and 78 percent of the average, respectively). As a whole, an average worker in the ICT and automobile industries produces 42 percent more value added than an average worker in the manufacturing industry.

These industries pay higher wages as well. Wages in TV/radio transmitters, TV/radio receivers, and motor vehicles industries are, on average, 181 percent, 47 percent, and 83 percent higher than those in the manufacturing industry. Although the automobile components industry is less productive than average, its workers are paid more than the average wage rate. As a whole, the ICT and automobile industries pay 59 percent higher wages. These figures indicate that if these industries continue to grow faster than the manufacturing average, they would have a positive impact on average productivity and wages by increasing their share in total manufacturing.

\subsection{Exports and Vertical Integration}

The recent performance of consumer electronics and automobile industries is seen most strikingly in export figures. As a result of the export boom achieved in the early 1980s, the value of manufactured exports jumped from US $\$ 2.2$ billion in 1980 to US $\$ 10.3$ billion in 1988 , and continued to increase at a lower rate until the mid-1990s (US\$14.4 billion in 1993). Export growth gained a momentum after the 1994 and especially 2001 crisis, and the value of manufactured exports reached US $\$ 30$ billion in 2001 and US $\$ 80$ billion in 2006 .

The share of consumer electronics and automobiles in total manufactured exports remained low until the early 1990s (each about 2 percent, see figure 13). Automobile exports started to increase their share after the 1994 crisis. Although the value of exports increased at a very rapid rate (average annual growth rate was about 10 percent from 1993 to 2001, and 20 percent from 2001 to 2006), automobile exports grew so fast that the share of automobiles in manufactured exports increased from 2.5 percent in 1993 to 16 percent in 2006. Consumer electronics also achieved a remarkable export performance. The share of consumer electronics in manufactured exports remained almost constant from 1989 to 1997 (2 percent), but afterwards it continuously increased to 4.6 percent in 2005 before declining to lower than 4 percent in 2006. ICT exports declined by 26 percent in the first quarter of 2007.11

\footnotetext{
11 The United Kingdom's CTV imports (GTP 8528) increased by 40 percent in 2006 compared to 2005 and reached 3.1 billion pounds, market share of Turkish CTVs declined from 19.2 percent in 2004 to 14.4 percent in 2006.
}

Integration with the Global Economy: The Case of Turkish Automobile and Consumer Electronics Industries 
The export performance of other ICT subsectors shows that Turkey could not achieve across-the-board growth in the ICT industry. Consumer electronics, or, more specifically, color television receivers (CTVs), was the only subsector of the ICT industry that achieved considerable level of exports. Exports of computing machinery, electronic components, and TV/radio transmitters remained at very low levels (US\$69, 36 and 40 million, respectively, in 2005) whereas exports of TV/radio receivers were US\$3,074 million in 2005 (from only US\$223 million in 1990; see table 3).

Figure 13: Manufacturing Exports and Shares of Automobiles and Consumer Durables (1989-2006)



Source: Turkstat.

Table 3: Export and Import Values on ICT and Automobile Industries in Turkey

\begin{tabular}{lrrrr}
\hline & \multicolumn{2}{c}{ Exports } & \multicolumn{2}{c}{ Imports } \\
\cline { 2 - 5 } & $\mathbf{1 9 9 0}$ & $\mathbf{2 0 0 5}$ & $\mathbf{1 9 9 0}$ & $\mathbf{2 0 0 5}$ \\
\hline Computing machinery & 20 & 69 & 467 & 2,465 \\
Electronic components & 3 & 36 & 429 & 1,695 \\
TV/radio transmitters & 14 & 40 & 164 & 1,765 \\
TV and radio receivers & 223 & 3,074 & 226 & 1,145 \\
Motor vehicles & 81 & 7,802 & 794 & 8,271 \\
Automobile bodies & 3 & 115 & 8 & 112 \\
Automobile components & 90 & 2,308 & 480 & 3,948 \\
Total (ICT and automobiles) & 433 & 13,445 & 2,568 & 19,401 \\
Total manufacturing & 10,400 & 6,7900 & 16,200 & 93,400 \\
\hline
\end{tabular}

Source: UNIDO, Industrial Demand-Supply Balance Database, 2007. 
Table 4: Direction of Foreign Trade in ICT and Automobiles, 1990 and 2005 (US\$ million)

\begin{tabular}{|c|c|c|c|c|c|c|c|c|}
\hline & \multicolumn{4}{|c|}{ Imports } & \multicolumn{4}{|c|}{ Exports } \\
\hline & Developing & $\%$ & Developed & $\%$ & Developing & $\%$ & Developed & $\%$ \\
\hline \multicolumn{9}{|l|}{1990} \\
\hline ICT components & 143 & 33 & 285 & 67 & 2 & 57 & 1 & 43 \\
\hline ICT products & 169 & 20 & 689 & 80 & 26 & 10 & 230 & 90 \\
\hline Automobile components & 8 & 2 & 480 & 98 & 18 & 19 & 75 & 81 \\
\hline Automobiles & 25 & 3 & 769 & 97 & 34 & 42 & 47 & 58 \\
\hline \multicolumn{9}{|l|}{2005} \\
\hline ICT components & 795 & 47 & 899 & 53 & 12 & 33 & 24 & 67 \\
\hline ICT products & 2,698 & 50 & 2,676 & 50 & 147 & 5 & 3,037 & 95 \\
\hline Automobile components & 345 & 8 & 3,715 & 92 & 625 & 26 & 1,799 & 74 \\
\hline Automobiles & 888 & 11 & 7,383 & 89 & 1,044 & 13 & 6,758 & 87 \\
\hline
\end{tabular}

Source: UNIDO, Industrial Demand-Supply Balance Database, 2007.

Note: ICT components: ISIC 3210; ICT products: ISIC 3000, 3220, and 3230.

Automobile components: ISIC 3420 and 3430; Automobiles: ISIC 3410.

The increase in exports of TV/radio receivers was accompanied by a sharp increase in the value of electronic components imports (from US\$429 million in 1990 to US\$1,695 million in 2005). Imports of TV/radio receivers increased at a lower rate in the same period and Turkey imported US\$1,145 million of TV/radio receivers in 2005.

Motor vehicle exports reached US\$7,802 million in 2005 and automobile components US $\$ 2,308$ million. Imports of motor vehicles and automobile components also increased as a result of integrating in the global production chains. Turkey imported US\$8,271 million of motor vehicles and US\$3,948 million of automobile components in 2005. Although Turkey is still a net importer of motor vehicles and components, the ratio of exports to imports increased substantially in the last couple of decades (from 14 percent in 1990 to 83 percent in 2005). Turkey is expected to be a net exporter in automobiles in a short time period.

Changes in the direction of foreign trade in ICT products and automobiles provide useful evidence on the mode of integration into the global economy (see table 4). ${ }^{12}$ One third of Turkey's imports of ICT components originated from the developing countries in 1990. However, the share of developing countries in Turkey's imports of ICT components increased gradually and reached 47 percent in 2005. A similar trend is observed in ICT products as well. The share of developing countries in Turkey's imports of ICT products increased rapidly, from 20 percent in 1990 to 50 percent in 2005. However, developed countries have become the main destination for Turkish exports of ICT components and products. Developed countries received 43 percent of Turkish exports of ICT

\footnotetext{
${ }^{12}$ Kaminski and $\mathrm{Ng}$ (2006) define automotive and ICT networks as "producer-driven" networks.
} 
components in 1990, and their share increased to 67 percent in 2005.13 They received the vast proportion of Turkey's exports of ICT products (that is, TV receivers) in 1990 (90 percent), and even increased their share in the last decade (95 percent in 2005). In other words, Turkey increasingly imports electronic components (and some ICT products such as computing machinery) from the developing countries, and sells final products made of these components to the developed countries (mainly the EU countries).

The direction of foreign trade in the case of automobiles is completely different. Turkey imports a large part of its automobile components and automobiles (final products) from developed, mainly EU, countries (97 percent in 1990 and 90 percent in 2005). A large proportion of Turkey's exports of automobile components goes to developed countries (81 percent in 1990 and 74 percent in 2005). Moreover, the developed countries have increased their share in Turkey's exports of automobiles, from 58 percent in 1990 to 87 percent in 2005. In other words, intra-industry trade has become more important between Turkey and the EU in automobiles and automobile components. ${ }^{14}$ Turkey both imports and exports these products at an increasing level to/from the EU, i.e. the Turkish automobile industry has fully integrated with the European production chains.

A comparative analysis is necessary in order to shed light on the determinants of modes of integration with the global economy. Table 5 presents the data on relative labor productivity, relative wages and unit labor cost in Turkey and a selected group of new and former members of the EU, and East European, Latin American and Asian countries. "Labor productivity" is measured as value added per employee (measured at current prices and exchange rate) relative to the level in the US. Relative wages are calculated in the same way. "Unit labor cost" is simply the ratio between wage bill and value added (divided by the US ratio), and shows the wage cost of producing one unit of value added. In order to reduce the effects of annual changes, the average values for the last five years for which the data are available for most of the countries in the sample are calculated.

\footnotetext{
${ }^{13}$ Note however that the value of Turkish exports of ICT components was very low, only US $\$ 3$ million in 1990 and US\$36 million in 2005.

${ }^{14}$ Since most automobile companies in Turkey are owned by multinational companies operating various manufacturing plants in European countries, a large part of intra-industry trade is indeed intra-firm trade. For example, Ford Otomotiv imported 2.4 billion lira of inputs (40 percent of sales revenue) from its parent company in 2005 (the Independent Audit Report for Year 2005 submitted to the Istanbul Stock Exchange).
} 




Integration with the Global Economy: The Case of Turkish Automobile and Consumer Electronics Industries 
Relative labor productivity data for the TV/radio receivers (ISIC 3230) sector show that Turkey is among the most productive countries in the sample. The level of productivity in Turkey exceeds all East European countries and Spain to a significant extent, somewhat higher than or equal to the level in developed EU countries (the United Kingdom and Germany), and higher than those of rapidly industrializing countries (Korea and Singapore). These results reflect outstanding productivity growth performance of the Turkish consumer electronics industries in the second half of 1990s. Relative wages in the Turkish TV/radio receivers sector are higher than those in East European and less-developed countries, but substantially lower than those observed in former EU countries (Spain, the United Kingdom, and Germany) and rapidly industrializing countries (Korea and Singapore). As a result, the (relative) unit labor cost in Turkey is lower than all European countries in the sample. There are only a few less-developed countries (Mexico, India, and Indonesia) that have lower unit labor cost thanks to their very low wage levels. Thus, it is not surprising that Turkish CTV producers have rapidly increased their exports to the EU in the second half of 1990s and early 2000s.

Motor vehicle (ISIC 3410) and automobile components (ISIC 3430) producers in Turkey are comparably less productive. Their productivity is about 24-27 percent of the U.S. level whereas relative labor productivity of Turkish TV/radio receiver producers is 51 percent. However, European producers are also poorly productive: the Slovak Republic, Poland, and Spain are less productive than Turkish producers, whereas the productivity differential between Turkish producers on the one hand, and British and German producers on the other hand, is not substantial. Wages in the Turkish automobile industry seem to be higher than those in Hungary, the Slovak Republic, and Poland, and much lower than those in Spain, the United Kingdom, and Germany. As a result, the unit labor cost is lower in Turkey than in European countries (with the exception of Hungary in our sample). Turkey has a cost disadvantage against most of less developed and rapidly industrializing countries (Mexico, Indonesia, Korea, Malaysia, and the Philippines). Apparently, Turkey has been increasing its automobile exports to the EU thanks to its low unit labor costs relative to European producers, and geographical proximity to main markets (and suppliers) that provides cost and delivery advantages over distant low-cost producers. Although automobile component producers in Turkey seem to be slightly more competitive than automobile producers, the patterns of productivity and wages in these two sectors are quite similar.

The data on the degree of vertical integration and product quality provide additional information on the structure of production and the mode of integration with the global economy. The ratio between value added and output value can be used as a first-order approximation for the degree of vertical integration in a given industry. If an industry does not purchase any input from other industries-that is, if the firms in that industry are fully vertically 
integrated - then the value added/output ratio will be equal to one. In the other extreme case where the industry purchases almost all inputs from others, it will not produce much value added and the ratio will get closer to zero.

The data on the value added/output show that Turkish industries are more vertically integrated especially relative to their counterparts in East European countries (see table 6). For example, in the TV/radio receivers sector, the United States has the highest value added/output ratio (0.35), followed by Germany, Japan, Korea, Brazil, and Turkey (all have value added/output ratios in the range of 0.29-0.32. It seems that the degree of vertical integration among Spanish and East European TV/radio receiver producers is quite low (the corresponding rates are 0.18 for Poland, 0.16 for Spain, 0.15 for the Slovak Republic, 0.14 for the Czech Republic, and 0.10 for Hungary). There is a similar pattern in the automobile and automobile components industries where Turkish producers have relatively higher value added/output ratios whereas East European producers have quite low shares of value added. There seems to be a significant difference in modes of integration to the global economy for Turkish and East European producers. It is likely that Turkish producers undertake more manufacturing operations whereas East European producers tend to rely on outsourcing components, or they themselves operate as subcontractors.

Table 6: Degree of Vertical Integration, Selected Countries (1998-2002 average values for value added/output ratio)

\begin{tabular}{llll}
\hline & $\mathbf{3 2 3 0}$ & $\mathbf{3 4 1 0}$ & $\mathbf{3 4 3 0}$ \\
\hline Turkey & 0.293 & 0.330 & 0.470 \\
Czech Republic & 0.140 & & 0.254 \\
Hungary & 0.096 & 0.180 & 0.298 \\
Slovak Republic & 0.154 & 0.116 & 0.292 \\
Poland & 0.177 & 0.168 & 0.314 \\
Spain & 0.155 & 0.154 & 0.298 \\
Brazil & 0.308 & 0.318 & 0.453 \\
Mexico & 0.276 & 0.262 & 0.317 \\
India & 0.154 & 0.177 & 0.265 \\
Indonesia & 0.270 & 0.604 & 0.322 \\
Korea, Rep. of & 0.309 & 0.384 & 0.387 \\
Malaysia & 0.133 & 0.222 & 0.352 \\
Philippines & 0.283 & 0.260 & \\
Singapore & 0.175 & 0.311 & 0.407 \\
United Kingdom & 0.263 & 0.183 & 0.352 \\
Germany & 0.317 & 0.222 & 0.351 \\
Japan & 0.311 & 0.253 & 0.307 \\
United States & 0.346 & 0.322 & 0.438 \\
\hline
\end{tabular}

Source: Calculated from UNIDO, Industrial Statistics Database, 2007.

Note: Czech Republic, 1998 and 2002; Poland, 1998-2000 and 2002; Malaysia, 2000-02; Mexico, 1998-2000; Philippines, 1998, 1999 and 2001; Turkey, 1998-2001.

All other countries, 1998-2002 averages. 
The average unit price of exported and imported passenger cars could be used as a measure of product "quality." The average (fob) unit price of passenger car exports was about 10-20 percent lower than the average (cif) unit price of imports in 1999 and 2000. The economic crisis 2001 and the devaluation of the Turkish lira in the same year led to a decline in export prices and an increase in import prices (denominated in U.S. dollars). The average unit price of exports tended to increase gradually, from US $\$ 7,600$ in 2002 to US $\$ 12,800$ in 2005, whereas the average unit price of imports remained almost the same (US\$13,200 in 2002 and 2005, see State Planning Organization, 2005: 24-27). Thus, the price differential between export and import prices declined up to 3-5 percent. Considering the cost of insurance and freight, one may conclude that there is not substantial quality difference, on average, between imported and exported passenger cars in Turkey. ${ }^{15}$

The improvement in the quality of products necessitates substantial investment in process renewal and new model development. According to the Automotive Manufacturers Association, the industry has invested on average about US\$400 million per year in the last decade. The level of investment declined considerably after the crises in 1994 and 2001, and reached the peak in 2006 (about US $\$ 1$ billion). The structure of investment has also changed in this process. Although the share of new model development investment was about 20 percent of total investment in the 1990s, it increased to 40-50 percent after 2000 to satisfy the demand for higher quality and more diversity.

\subsection{Firm-Level Performance}

The automobile and consumer electronics industries have undergone a process of transformation in the last decade, and the outcome of this process has been observed in recent years. Since official sectoral-level data for recent years are not available, firm-level data could provide additional information about this transformation process.

The Automotive Manufacturers' Association (the Turkish acronym is OSD) is the main umbrella organization for the automobile producers in Turkey. All major producers are members of the organization. Six passenger car producers have foreign participation (four are majority foreign owned). ${ }^{16}$ There are 12 other companies (5 of them foreign owned) that produce trucks, pickups, buses, minibuses, and road and farm tractors. Thus, the automobile industry is dominated by foreign companies.

There are a large number of suppliers located mainly in the Marmara region. The Association of Automotive Parts and Components Manufacturers (TAYSAD)

\footnotetext{
15 The average unit price is determined by a large extent the composition of imports/exports. We implicitly assume that there is not much change in the composition of imports/export during the period under investigation.

${ }^{16}$ Home countries: EU (2), Japan (2), United States (1), and Korea (1).
} 
has 236 members. ${ }^{17}$ There are 40 foreign companies (most of them are majority owned) among TAYSAD members. ${ }^{18}$

There are three major producers in the consumer electronics sector: Arçelik, Beko, and Vestel (Arçelik and Beko are subsidiaries of Koç Holding). Beko and Vestel are specialized in consumer electronics whereas Arçelik produces other consumer durables (the so-called "white-goods" and household appliances) as well. None of these companies have any foreign participation (for more information, see Ozcivelek and Zontul, 2004).

A number of automobile and consumer electronic companies are listed on the Istanbul Stock Exchange (see table 7). The financial statements of these companies are audited by independent auditors and are publicly available. Thus, the financial data on listed companies could be used to shed light on recent changes in these sectors.

Table 7: Major Automobile and Consumer Electronic Producers Listed on the Istanbul Stock Exchange in Turkey

\begin{tabular}{|c|c|c|c|c|}
\hline & Employees & Export rate & Import rate & F/D \\
\hline \multicolumn{5}{|l|}{ Automotive } \\
\hline Anadolu Isuzu & 741 & 15.0 & 34.0 & $\mathrm{~F}$ \\
\hline Ford Otosan & 7,722 & 42.7 & 63.0 & $\mathrm{~F}$ \\
\hline Karsan & 957 & 3.5 & 61.8 & $\mathrm{D}$ \\
\hline Otokar & 988 & 37.0 & 43.0 & $\mathrm{D}$ \\
\hline Tofaş & 4,379 & 48.7 & 46.1 & $\mathrm{~F}$ \\
\hline \multicolumn{5}{|l|}{ Parts and components } \\
\hline Bosch Fren Sistemleri & 246 & 81.2 & 57.0 & $\mathrm{~F}$ \\
\hline Ditaş Doğan & 576 & 41.0 & 24.0 & $\mathrm{D}$ \\
\hline Ege Endüstri & 474 & 59.0 & 25.0 & $\mathrm{D}$ \\
\hline F-M İzmit Piston & 24 & 22.3 & 4.1 & $\mathrm{D}$ \\
\hline Mutlu Akü & 561 & 36.0 & 55.0 & $\mathrm{D}$ \\
\hline Parsan & 565 & 66.0 & 33.0 & $\mathrm{D}$ \\
\hline \multicolumn{5}{|l|}{ Consumer electronics } \\
\hline Arçelik & 9,203 & 27.5 & 47.0 & $\mathrm{D}$ \\
\hline Beko & 3,907 & 76.3 & 65.2 & $\mathrm{D}$ \\
\hline Vestel & 11,286 & 75.4 & 50.0 & $\mathrm{D}$ \\
\hline
\end{tabular}

Source: Istanbul Stock Exchange.

Notes: 2005 data for the number of employees, export rate, and import rate. Export rate is the share of exports in sales revenue. Import rate is the proportion of imported inputs to sales revenue.

\footnotetext{
17 The member companies of OSD and TAYSAD employed 42,700 and 66,000 people, respectively, in 2006 (see the organizations' Web sites: http://www.osd.org.tr and http://www.taysad.org.tr).

${ }^{18}$ Home countries: EU (25), Japan (8), United States (5), Korea (2), and Switzerland (1).
} 
The data on net real sales of these companies show that especially large final producers (Ford and Tofaş in automobiles and Arçelik, Vestel, and Beko in consumer electronics) achieved rapid growth in sales after the 2001 crisis, and reached peak sales in 2004-05 (see figure 14). ${ }^{19}$ The increase in sales is striking given almost a decade-long stable level of sales of those companies until 2001.

The export data at the firm level reveal that automobile and consumer durables producers reacted swiftly to the 2001 crisis and the devaluation of the Turkish lira, and increased export rates substantially in 2001 and 2002 (see figure 15). The lira appreciated rather rapidly after the crisis until 2006, so much that it was (in real terms) 25 percent overvalued in 2005 compared to 2000. In spite of the appreciation of the lira, the automobile and consumer electronic producers were successful in keeping their export rates at a level higher than the pre-crisis level. Apparently, their export intensity reached and remained at a higher plateau after the crisis.

The automobile and consumer electronic producers experienced, on average, declining profitability ${ }^{20}$ in the second half of 1990s that hit bottom during the 2001 crisis. They gradually recovered after the crisis and the profit margin increased to positive numbers in 2002 and 2003. However, the profit margin has remained at low levels (3-4 percent, weighted average) over the past few years without any sign of recovery (see figure 16).

Figure 14: Net Sales of Automobile and Consumer Electronic Companies in Turkey (million TL, 1993 prices)



Source: Istanbul Stock Exchange.

19 Sales values are deflated by GDP deflator.

${ }^{20}$ Profit margin is measured as new profit after taxes/net sales ratio. 
Figure 15: Export-Output Ratio of Automobile and Consumer Electronic Companies in Turkey, 1998-2005


Source: Istanbul Stock Exchange.

Figure 16: Net Profit Margin of Automobile and Consumer Electronic Companies in Turkey, 1993-2006 (net profit after taxes/net sales)



Source: Istanbul Stock Exchange. 
The profitability data show that these producers operate on thin margins, and their sales revenues are only slightly more than their expenses. In other words, price competition seems to be very important especially for consumer electronics producers.

\section{Macroeconomic Policies and Sectoral Performance}

\subsection{Automobiles}

The automobile industry in Turkey has proved to be a vibrant and growing sector, and achieved an outstanding export performance in the last decade in spite of the macroeconomic problems that plagued the country. What are the main factors behind its performance?

The automobile industry is well integrated within international production chains. From its inception in the 1960s and 1970s until the late 1990s, foreign firms, either through joint ventures with major domestic business groups or through wholly owned subsidiaries, have been dominant in the industry. Although these companies were oriented toward the domestic market until the early 1990s, they were able to seize new market opportunities opened by the CU with the EU in 1996. New foreign companies entering the Turkish market in the second half of 1990s have targeted the EU market as well. These companies have strong links with their subsidiaries in the EU, and intra-firm trade has apparently played an important role in producing automobiles in Turkey and marketing them in the EU countries.

Although the automobile industry is well integrated within international, or, more specifically, European production chains, it has also benefited to a large extent from the existence of a strong domestic industrial and supplier base. The automobile parts and components sector developed to some extent in the 1970s and 1980s, and attracted foreign investment in the 1990s. Strong and responsive supplier-producer links have enabled automobile producers to expand their capacity and output rapidly after the 2001 crisis (for a comprehensive analysis of supplier-buyer links, see Wasti, Kozan, and Kuman, 2006).

The automobile industry in Turkey would not be successful had it failed to adapt itself quickly to new conditions imposed by the CU. The OSD played an instrumental role in anticipating new challenges and orchestrating a common course of action to face these challenges. The OSD regarded the CU as an inescapable fact, and considered it as an opportunity in the early $1990 \mathrm{~s}^{21}$ The first challenge was to adopt massive EU rules and regulations affecting the industry. The process of discovering, understanding, and transposing EU rules and

${ }^{21}$ During the negotiation stage of the CU agreement, the automobile industry was expected to be one of the industries that would face the toughest competition from the EU-origin imports. Thanks to forceful lobbying by the industry, full liberalization of the automotive imports was phased in over a period of five years. 
regulations proved to be useful in enhancing the competence of technical personnel employed by automobile producers (and government officials). After achieving a certain level of technological sophistication necessary to satisfy the EU rules, the technical personnel pushed forward to improve quality and to introduce new designs (especially in the commercial vehicles segment) to be more competitive in the EU market. "Research and development" became a catchword in the late 1990s. Current plans drawn by industry representatives are targeted to make Turkey the third-largest producer in Europe by 2013 as well as making it a center for design and research and development. ${ }^{22}$

\subsection{Consumer Electronics}

The structure of the consumer electronics industry in Turkey is rather different than that of the automobile industry. The consumer electronics industry is dominated by a few large domestic firms that are not supported by any domestic supplier base. Consumer electronics producers use mostly commercial off-theshelf components and import them from East Asian and European countries. The domestic electronics components sector is almost nonexistent, and consumer electronics producers outsource only some nonelectronic parts to local suppliers.

The components used by consumer electronic producers (the most important being the cathode ray tube (CRT) for color television receivers) and their final products are commodity-like products sold in almost perfectly competitive markets where profit margins are razor thin. Moreover, CRT televisions are perceived as "old technology" and are being displaced by new technology like LCD and plasma televisions in developed country markets.

Under those adverse conditions, the Turkish consumer electronics producers have become quite successful in the EU market by producing the right product at the right time in the right place.

In the 1990s, CRT television technology was a mature technology and new LCD and plasma technologies were expected to displace rapidly CRTs, especially in the large-screen television market. This means that technological entry barriers were low in this market segment, which European producers eventually would be forced to exit. In other words, the CRT color television segment, which was still the largest television segment during the 1990s in the EU, was the only segment where new producers would enter. Turkish TV producers have become competitive in this market thanks to their flexibility and low-cost manufacturing.

When Turkish producers entered into the EU market en masse in the mid1990s (right after the CU in 1996), Asian producers had low production costs and were competitive against Turkish producers that rapidly increased their productivity over time. However, that was the right time to enter the EU market because the European Commission imposed provisional (1994) and definitive (1995 and 2002) antidumping duties on color television receivers originated in

\footnotetext{
${ }^{22}$ Interview with Ercan Tezer, the Secretary General of the Automotive Manufacturers' Association, April 4, 2007.
} 
China, Malaysia, Korea, Thailand, and Singapore. ${ }^{23}$ The European Commission initiated antidumping proceedings concerning imports of color television receivers originated in or exported from Turkey in 1992 and 2000, and decided not to impose any duty. ${ }^{24}$

Since Vestel imported CRTs from China and Beko from Malaysia and Korea, they were subject to antidumping duties for their products originating from these countries, but the level of duties were much lower. For example, the rate of duty, set in the Council Regulation 1531/2002 that is still in force, is 44.6 percent for Chinese producers whereas it is only 24.5 percent for Vestel for CTVs assembled in Turkey that incorporate CRTs originated from China. ${ }^{25}$ The time was right because, as a member of Vestel's Executive Committee admits, "[i]n 2000, if the additional taxes to Chinese producers were lifted, it would have been devastating for Vestel" (Cengiz Ultav, quoted by Karabati and Tan, 2005: 7). Vestel has become one of the largest and competitive producers in Europe thanks to its investment in flexible automated process technologies, effective global sourcing, and quick response and point delivery capabilities. In other words, the EU antidumping measures imposed on low-cost Asian producers provided Turkish producers a kind of "infant industry protection" at a crucial time.

Finally, Turkish consumer electronics producers were located in the right place. They were located very close to a major market (the EU), and employed skilled labor at low cost. Geographical proximity provides cost advantages over Asian producers but more importantly it helps to reduce the delivery time. According to Karabatı and Tan (2005), the delivery time to Europe is 1-2 weeks for Vestel, but 1.5-2 months for Chinese producers. Thus, Turkish producers can operate on a "made-to-order" basis, thanks to their short delivery time and manufacturing flexibility.

23 The antidumping measures in place regarding imports originating in Singapore remained in force until 2002. For antidumping measures, see the Council Regulations 2376/94, 710/95 (amended by $2584 / 98$ ) and $1531 / 2002$ (amended by $511 / 2006$ ).

${ }^{24}$ See the European Commission Decisions 95/92 and 2001/725. The Commission's decision is based on the following argument: " $\ldots$ the origin of the cathode-ray colour television picture tube (CPT) virtually determined the origin of the CTVs, since the ex-works price of the CPT represented, in all cases, at least 35 percent of the ex-works price of the CTV. It should be noted that there is no production of CPTs in Turkey and, therefore, all CPTs are imported. Accordingly, the origin examination concluded that the CTVs exported from Turkey during the [investigation period] were of the origins of the CPTs used in their assembly." (the Commission Decision of 28 September 2001, 2002/725).

25 The rates are 25.1 percent for Malaysia and 15.0 percent for Korea whereas Beko is subject to 18.2 percent and 12.3 duty for its CTVs originating from Malaysia and Korea, respectively. The European Commission accepted a joint undertaking with seven Chinese TV producers and the China Chamber of Commerce for Import and Export of Machinery and Electronics Products and waived the antidumping duty on these companies on the condition that they would respect minimum import price levels and quantitative ceilings established by the Commission. The European Commission has re-imposed a 44.6 percent antidumping duty on imports of Chinese color television receivers after one of the companies refused to allow the EU to inspect its premises in 2006 (see the Commission Decision 2006/258 and the Council Regulation 511/2006). 


\subsection{Lessons Learned}

The history of the Turkish economy over the last quarter century leaves no doubt that successive governments failed to put the country on a sustained growth path. Despite policies that ascertained the external adjustment, governments failed to undertake the right mix of policies to insure internal adjustment and create an economic environment conducive for long-term investment. The performance of the automotive and consumer electronics industries, on the other hand, showed that despite the macroeconomic policies that inhibit investment and growth, certain sectors can perform well enough to integrate with the world markets.

The success of the automotive and consumer electronics industries has much to do with increased competition after the $\mathrm{CU}$ rather than macroeconomic policies. Had Turkey adopted the correct mix of macroeconomic and sectoral policies in the 1990s, the majority of the other manufacturing sectors would have realized structural transformations similar to that of the two sectors. As a result, Turkey could have undertaken the transformation from a lower middle-income economy with competitive advantage in labor-intensive sectors, into a higher middle-income country with increased focus on technology-intensive sectors.

The statistics on FDI inflows during the 1990s provide additional evidence about the role of the macroeconomic environment. Throughout the 1990s, a period during which the global capital flows increased exponentially, Turkey was not able to increase the FDI inflows. Average annual FDI inflows during the 1990-2004 period were below US\$1 billion. Multinational corporations (MNCs) decided not to invest in new projects in Turkey during this period of uncertainty, and some decided to close their factories in the country. While Turkey was tied up with its domestic political and economic uncertainty, its competitors in the developing world and among the transition economies adopted the right mix of policies that enabled them to attract billions of dollars in FDI every year. For example, throughout the late 1990s and early 2000s, the Czech Republic, Hungary, and Poland attracted close to US\$5 billion a year, whereas Turkey attracted less than US $\$ 1$ billion a year.

While both sectors have done quite well after the $\mathrm{CU}$, the impact of the $\mathrm{CU}$ on the two industries differed substantially. In the case of consumer electronics, the CU enabled Turkish consumer electronics companies to multiply their exports to the EU market in a very short period, as they were confronted with very few barriers to entry. Their ability to capture a large share of the EU market for the traditional CRT TVs owed a lot to the trade barriers that EU raised towards imports from the East Asia and China. In order to achieve this, companies in the consumer electronics did not have to undertake large investment expenditures on new product development and innovation. Instead, they needed to create huge capacities to take advantage of scale economies in production, especially of CRT color TVs. 
This rather easy transformation of the sector into an export sector with close to 50 percent of the EU market for CRT TVs has created new challenges. Without investing in new technology, the sector was excessively dependent on component imports from East Asian countries. The value added at the firm level was quite small even in CRT TVs and further declined with the widespread commercialization of plasma and LCD televisions, and profitability eroded tremendously.

After years of upward trends, the sector's output declined by 16 percent in 2006 and by 33 percent in the first four months of 2007. Without developing its own technology and increasing its value added, the industry will be facing more serious threats in the coming years. Turkey's geographical proximity to Europe used to be viewed as an important advantage for Turkish ICT producers against the East Asian and Chinese producers. In order to overcome this advantage, in recent years the East Asian and Chinese producers founded LCD and plasma TV factories in the Central and Eastern European countries.

In the early 1990s, there was no reason for the automotive industry to change the way it ran the business. However, in the 10 years following the formation of the CU between Turkey and the EU, the Turkish auto industry went through a serious transformation. The seeds of change came about in the early 1990s. The trade liberalization throughout the late 1980s and early 1990s reduced the protection against the motor vehicle imports. However, as the domestic demand was booming, the industry was performing quite well in terms of profits. Import penetration was rather small thanks to the still-high protection rates.

The most significant step in the transformation was the formation of the $\mathrm{CU}$ between Turkey and the EU. During the negotiation stage of the CU agreement, the Turkish auto industry was expected to face tough competition from EUorigin imports. The industry did not hide this fact and forcefully lobbied the government to gain as much time as possible in order to postpone the full impact of the CU. As a result, the auto industry was one of the sensitive sectors that Turkish side wanted to include in the agreement. Full liberalization of auto imports was phased in over a period of five years. Imports of used cars are still prohibited and likely to continue that way in the near future.

Immediately before the formation of the CU in 1996 there was no serious change in the policies of the industry to prepare for competition. However, despite the clauses that were incorporated in the CU agreement to slow down the penetration of imports, imports surged very rapidly, accounting for half of the market by 1998. As the domestic producers recognized the threat from imports they started to make investments that would keep them competitive. However, these efforts could not bear fruit until late 1999 and 2000. Until then the Turkish auto industry continued to rely mostly on the domestic market. As a result of the investment projects the producers started to develop models that could compete with foreign-built cars domestically and internationally. 
A natural implication of Turkey's large domestic market is the presence of FDI directed largely towards the domestic market. However, the automotive sector is a good example of how an initially protected home market can be transformed into a competitive and increasingly export-oriented industry through FDI inflows coupled with the availability of low-cost, highly qualified labor. During the debate on the $\mathrm{CU}$, the automotive sector was expected to be the worst affected from lowering protection on EU imports. However, that prediction was proven wrong. Over the last couple of years, the automotive sector has become the second-largest export sector.

By the mid-1990s, there were four MNCs with a sizeable market share and more than 20 years of experience in the Turkish automotive industry (Fiat, Ford, Mercedes Benz, and Renault). ${ }^{26}$ In the mid-1990s, with the increasing prospects of a CU agreement with the EU, Japanese and Korean companies (Honda, Hyundai, and Toyota) started investing in Turkey in joint ventures with Turkish industrialists or, as in the case of Isuzu, expanding existing joint ventures. ${ }^{27}$ Perhaps because of the uncertain business environment in Turkey, these companies did not make substantial investments initially and built plants with small production capacity (in the vicinity of 10-20,000 units per year). Once the CU with the EU went into effect in 1996, the domestic market gradually opened up to competition from the EU. Actually, in the first couple of years of the CU, the sector struggled with wild fluctuations in domestic demand as well as competition from imports. The contagion from the Russian crisis of 1998 and the Marmara earthquake of 1999 effectively hit the demand in the auto market.

However, there was a lot at stake. There was already substantial production capacity coupled with a competitive parts and accessories industry. In addition, domestic business establishments with years of experience in the automotive industry and cheap but good-quality labor induced MNCs in the automotive sector to increase their investments in Turkey and built new capacity to produce motor vehicles for the European market. None of the MNCs mentioned above decided to close down their plants in Turkey. ${ }^{28}$

The auto parts and accessories industry also has been attracting foreign investors. Most of the world leaders of the sector have joint ventures with Turkish partners. Some of them are big suppliers like Robert Bosch, Valeo, Delphi Packard, and Mannesmann Sachs. Altogether, between 1992 and 2000, the automotive industry realized US\$3.4 billion worth of investment. Of this amount,

\footnotetext{
${ }^{26}$ Obviously there were other producers active in the domestic market. The listed four had the largest market shares in the automotive industry.

${ }^{27}$ Of these four MNCs, Toyota and Honda decided to become the sole owners of their production units (and Hyundai increased its shares to 70 percent) once they decided to target their production towards the European market rather than the domestic market. This fact can be taken as an example of the difficulty that foreign investors face when entering the domestic market without an insider on board.

${ }^{28}$ Only Opel closed down its small plant near Izmir that was used to undertake the assembly of some of its car models.
} 
US\$750 million was used for capacity development, US\$976 million for new model development, US\$497 million for modernization, US\$300 million for localization, and US\$195 million for quality improvement. Moreover, due to new investment projects towards the production of new models, in recent years this investment amount increased by close to US $\$ 1$ billion.

\section{Sustainability, Institutional Change, and Political Economy of Reform}

Even though Turkey had traveled a long distance since 2001 crisis, the Turkish economy still faces challenges. These challenges, mostly driven by domestic institutional factors, cannot be resolved on a permanent basis without reforming the country's political system, shaped by the current legal and institutional framework. The 1982 constitution, the election law, and, most important, the political party law passed by the military regime created an environment that gives the political elites autonomy from the scrutiny of the rank-and-file of the political parties and the society at large.

Political parties are the cornerstones of western-style democracies, through which political competition is realized. Unfortunately in the Turkish political system that is not the case. The current political party and election laws were not designed to promote the fundamental principles of political democratic competition.

Since it was founded in 1923, the Turkish Republic has been governed by military and civil bureaucratic elites. With the 1946 elections the country made its transition to democracy. In the 1950 elections, the power was transferred away from the Republican People's Party (RPP) that represented the single-handed rule of the bureaucratic elites. As democracy has taken hold in the country, political elites started to share power with the bureaucratic elites. Since then, three military interventions and the ensuing changes in the constitutional and institutional framework have laid the foundations for the current political system.

The current political party and election laws raise significant barriers to entry and exit, and hence curtail democratic competition within the political parties. Each political party is captured by a group of political elites who are involved in patronage, populism, and rent seeking activities at different stages. Once a group of political elites capture the party leadership, they never surrender it to the opposition in the party.

As the current political party law gives all the power to the party headquarters, the party leadership controls the channels through which the party rank and file can replace the leaders/cadres that are proven to be unsuccessful. As a result, the rank and file has very little chance of removing the leadership. The party headquarters can annul the local chambers of the party and appoint 
new members. Consequently, in the Turkish political system, political parties have become nothing more than the fiefdoms of the party leaders and their immediate supporters. Members who oppose the leadership have no chance of survival within the party. As the political party law does not allow the democratic channels to function properly, those members that are thrown out of their parties can continue their political activities in another party or form a new party themselves.

There are several consequences of this political system. A plethora of political parties has emerged with short life spans. There is rapid turnover of the parties in the government. These phenomena could be observed in the Turkish political landscape over the last two decades.

Over the last 20 years, the election performances of the two center-right parties, the Motherland Party (MP) and the True Path Party (TPP), provide excellent examples of what the hegemony of political elites imply for the parties in the long run. The two parties together received 55 percent of the popular vote in the 1987 general elections, which was the first democratic election after the 1980 coup d'etat (see figure 17). However, both parties were controlled by the political elites so much that until the November 2002 general elections they were unable to replace their unsuccessful leaders, Tansu Çiller and Mesut Yilmaz. Yilmaz stayed as the chairman of the MP for more than 11 years and Çiller was at the helm of the TPP for more than 9 years. Yilmaz lost five elections in a row, including the local elections, whereas Çiller lost four elections. With Yilmaz at the helm, the MP's voter support declined from 24 percent in the 1991 elections to 5.1 percent in the 2002 elections. Similarly, the TPP's votes declined from 27 percent in 1991 to 9.6 percent in 2002 under Çiller's leadership (see figure 17)

Despite their proven track records, neither of the parties was able to replace their respective leaders. The political party law enabled both leaders to exert complete control over the whole party organization. Offering no real solution to major economic problems and unable to change the unsuccessful and unpopular leaders, popular support for the center-right and center-left parties eroded over time; so much that in the November 2002 general elections, the two parties could gather a total of only 14 percent of the popular vote. Thanks to the undemocratic threshold imposed by the election law, neither party was able to gain seats in the parliament. The leaders were finally pushed out, but only after this major defeat. It was rather too late. The two center-right parties that once appealed to more than half of the voters are currently facing extinction.

Another important consequence of the existing barriers of entry and exit in party politics is the proliferation of political parties and fragmentation of politics. Whereas only 7 political parties participated in the 1987 general elections, 21 parties participated in the nationwide campaign for the April 1999 elections and 18 parties participated in the November 2002 elections. 
Figure 17: General Election Results, 1987, 1991, 1995, 1999 and 2002


Source: Turkstat.

Note: See table below for a list of political parties and their acronyms.

\section{Major Turkish Political Parties}

\begin{tabular}{lll}
\hline Acronym & Turkish & English \\
\hline AKP & Adalet ve Kalkınma Partisi & Justice and Development Party \\
ANAP & Anavatan Partisi & Motherland Party \\
CHP & Cumhuriyet Halk Partisi & Republican people's Party \\
DEHAP & Demoratik Halp Partisi & Democratic People's Party \\
DSP & Demokratik Sol Parti & Democratic Left Party \\
DYP & Doğru Yol Partisi & True Path Party \\
FP & Fazilet Partisi & Virtue Party \\
GP & Genç Parti & Young Party \\
HADEP & Halkın Demokrasi Partisi & People's Democracy Party \\
MÇP & Milliyetçi Çalışma Partisi & National Work Party \\
MHP & Milliyetçi Hareket Partisi & National Action Party \\
RP & Refah Partisi & Welfare Party \\
SHP & Sosyal Demokrat Halk Partisi & Social Democratic People's Party \\
SP & Saadet Partisi & Felicity Party \\
\hline
\end{tabular}


As the popular support base of the center parties eroded, there was a struggle to capture center-right and center-left votes. Tired of the past failures and the increased cost of living with every election, voters used their only democratic choice - to try a party that had not been tested before. In the 1999 and 2002 general elections, marginal parties received the bulk of the votes and formed the government. Once they became coalition partners, these parties declared repeatedly that they were actually parties closer to the center. Since the constraints and incentives faced by the political elites controlling these parties were no different from the parties that ruled the country before, they had no reason to stop transferring government resources to elites and start delivering solutions to the age-old problems of the country.

Going into the November 2002 elections, all major political parties on the right and the left had taken part in government before. The current ruling Justice and Development Party (JDP), an offspring of the Welfare Party, which was founded only 15 months before the elections, was the only untested party that completed its country-wide grass-roots organization. Being the only untested party with a potential appeal to the electorate, JDP made good use of this golden opportunity.

Before the 2002 elections, JDP leaders were proudly announcing how democratic their party by-laws were, ensuring the active participation of the party rank and file in the decision-making process. However, just three months into power, the Founders' Council of JDP decided to change several articles in the party bylaws to make sure that the chairman and the party headquarters are in complete control of the party. JDP now is no different from other parties that it had so vehemently opposed and criticized before the elections for lacking the within-party democracy. They are also not much different from the political elites in other parties in terms of making good use of the government resources to support the businesses close to the party. There have been numerous news reports over the last four and a half years that document the JDP's decisions to grant major local and central government investment projects to businesspeople linked with the party.

The incentives and constraints the political elites are facing have to be rewritten in order to ensure that both political and economic stability will be sustained in the medium to long term. Unless the current political party and election laws are scrapped and new laws that promote and guarantee withinparty political competition are adopted, the political elites will behave no differently than their predecessors. Without these major political reforms, the future general elections will not insure that micro "supply-side" economic reforms that have been delayed for so long will be implemented in the near future and the growth performance of the last five years will be sustained in the long-run. To the contrary, as the political opposition in the parliament will become stronger in the future, the JDP may turn to more populist policies; just as 
the "reformer" Turgut Özal favored populist policies when his party faced strong opposition in the parliament after the 1987 general elections.

The upshot of this short political economy analysis is that Turkey will not be able escape the populist cycles of the 1990s and the ensuing economic crises unless it reforms the current political party law, the constitution, and the election laws to establish public control over the political elites. Unfortunately, it is not in the interests of political elites to undertake these reforms.

\section{Conclusions}

The development of the Turkish economy since the early 1990s shows that despite the macroeconomic policies and conditions inhibiting investment and growth, certain industries performed very well and played an important role in generating employment and fostering growth. The automobile and consumer electronics industries are certainly among the most successful industries in Turkey in the last decade. These two industries have achieved remarkable output and productivity growth rates, and have been very competitive in international markets.

Although there are similarities between the performance of the automobile and consumer electronic industries, there seems to be significant differences between their structures, links with domestic suppliers, technological orientation, and modes of integration with the global economy. The automobile industry is dominated by multinational companies, has a strong domestic supplier base, and has seized the opportunities opened up by the CU by investing in new product and process technology and learning. Both the final product and supplier segments of the industry are well organized, and have established a shared vision of the future through organized dialogue within the industry and with the public sector as well. Industrial leadership, coordination, and cooperation have been vitally important for the success of the automobile industry.

The consumer electronics industry is dominated by a few, large, domestic firms, and has become competitive in the European market thanks to its geographical proximity, productive domestic labor, and focus on a protected and technologically mature niche market, namely CRT TVs. The market is characterized by almost "perfect competition" with very low profit rates, and is being replaced by technologically advanced substitutes-that is, large-screen LCD and plasma televisions. Therefore, the Turkish consumer electronics industry is under severe competitive pressures and will revitalize itself only if it can achieve a breakthrough in its technological orientation.

Our analysis suggests that neither the automobile nor the consumer electronics industries have directly benefited from macroeconomic policies in the 1990s. On the contrary, they have been successful under adverse macroeconomic 
conditions, and have increased their exports after crises, especially after the worst one in 2001. However, this does not mean that macroeconomic policies and environment are inconsequential for industrial performance and economic growth. Without a doubt, these industries and others that did not perform so well in the last decade would have performed even better had governments in Turkey adopted more responsive macroeconomic policies. However, governments will be more responsive only if far-reaching political reforms are undertaken, including changing the constitution and current political party and election laws in order to establish public control over the political elites. 


\section{References}

Çakır, E. 2004. Televizyon Sektör Raporu [Report on the Television Industry]. Istanbul: Istanbul Chamber of Commerce (ITO).

Kaminski, B., and F. Ng. 2006. “Turkey's Evolving Trade Integration into PanEuropean Markets." Policy Research Working Paper 3908. World Bank, Washington, D.C.

Karabati, S., and B. Tan. 2005. "Vestel Electronics: Transition to the Leading European TV Manufacturer." Graduate School of Business Case Study No. 605-015-1. Koc University, Istanbul.

Ozcivelek, R., and H. Zontul. 2004. "Insights into the ICT Industry in Turkey." Technical Report EUR 21392 EN. The Institute for Prospective Technological Studies (IPTS), Seville.

State Planning Organization, Turkey. 2005. Dokuzuncu Kalkınma Planı (2007-2013) Otomotiv Sanayii Özel İhtisas Komisyonu Raporu. Ankara: SPO.

Şenses, F., and E. Taymaz. 2003. “Unutulan Bir Toplumsal Amaç: Sanayileşme Ne Oluyor? Ne Olmalı?" [A Social Objective Forgotten: Industrialization]. In A. H. Köse, F. Şenses, and E. Yeldan, eds., İktisadi Kalkınma Kriz ve İstikrar, İstanbul: İletişim.

Taymaz, E., and K. Yilmaz. 2007. "Productivity and Trade Orientation: Turkish Manufacturing Industry Before and After the Customs Union." Journal of International Trade and Diplomacy (1): 127-54.

Togan, S. 1997. "Opening up the Turkish Economy in the Context of the Customs Union with EU." Journal of Economic Integration (12): 157-79.

Wasti, S. N., M. K. Kozan, and A. Kuman. 2006. “Buyer-Supplier Relationships in the Turkish Automotive Industry." International Journal of Operations and Production Management (26): 947-70.

Yılmaz, K. 2007. Türkiye için Doğrudan Yabancı Yatırım Stratejisi'ne Doğru [Towards a Foreign Direct Investment Strategy for Turkey]. Istanbul: International Investors Association of Turkey (YASED). 



\section{Eco-Audit}

\section{Environmental Benefits Statement}

The Commission on Growth and Development is committed to preserving endangered forests and natural resources. The World Bank's Office of the Publisher has chosen to print these Working Papers on 100 percent postconsumer recycled paper, processed chlorine free, in accordance with the recommended standards for paper usage set by Green Press Initiative-a nonprofit program supporting publishers in using fiber that is not sourced from endangered forests. For more information, visit www.greenpressinitiative.org.

The printing of all the Working Papers in this Series on recycled paper saved the following:

\begin{tabular}{|c|c|c|c|c|}
\hline Trees* & Solid Waste & Water & Net Greenhouse Gases & Total Energy \\
\hline 48 & 2,247 & 17,500 & 4,216 & 33 mil. \\
\hline $\begin{array}{c}{ }^{*} 40 \text { inches in } \\
\text { height and 6-8 } \\
\text { inches in diameter }\end{array}$ & Pounds & Gallons & Pounds CO2 Equivalent & BTUs \\
\hline
\end{tabular}




\section{The Commission on Growth and Development Working Paper Series}

28. The U.S. Subprime Mortgage Crisis: Issues Raised and Lessons Learned, by Dwight M. Jaffee, June 2008

29. The Automotive Industry in the Slovak Republic: Recent Developments and Impact on Growth, by Malgorzata Jakubiak and Peter Kolesar, June 2008

30. Crime and Growth in Colombia, by Mauricio Cardenas, June 2008

31. Chilean Growth Through East Asian Eyes, by Homi Kharas, Danny Leipziger, and R. Thillainathan, June 2008

32. Population Aging and Economic Growth, by David E. Bloom, David Canning, and Günther Fink, July 2008

33. Early Life Nutrition and Subsequent Education, Health, Wage, and Intergenerational Effects, by Jere R. Behrman, July 2008

34. International Finance and Growth in Developing Countries: What Have We Learned, by Maurice Obstfeld, August 2008

35. Policy and Institutional Dynamics of Sustained Development in Botswana, by Gervase Maipose, August 2008

36. Exports of Manufactures and Economic Growth: The Fallacy of Composition Revisited, by William R. Cline, August 2008

37. Integration with the Global Economy: The Case of Turkish Automobile and Consumer Electronics Industries, by Erol Taymaz and Kamil Yılmaz, August 2008

\section{Forthcoming Papers in the Series:}

Political Leadership and Economic Reform: the Brazilian Experience, by Henrique Cardoso and Eduardo Graeff (September 2008)

Philippines Case Study: The Political Economy of Reform during the Ramos Administration (1992-98), by Romeo Bernardo and Christine Tang (September 2008) 
$\mathrm{T}$ his paper provides an extensive case study of Turkey's automotive and consumer electronics industries. Despite a macroeconomic environment that inhibits investment and growth, both industries have achieved remarkable output and productivity growth since the early 1990s. Although there are similarities between the performances of the two industries, there are significant differences between their structures, links with domestic suppliers, technological orientation, and modes of integration with the global economy. The automobile industry is dominated by multinational companies, has a strong domestic supplier base, and has seized the opportunities opened up by the Customs Union by investing in new product and process technology and learning. The consumer electronics industry is dominated by a few, large, domestic firms, and has become competitive in the European market thanks to its geographical proximity, productive domestic labor, and focus on a protected and technologically mature segment of the market, which also helps explain the recent decline in industry's fortunes. These industries could have performed even better had far-reaching political/institutional reforms been undertaken to establish public control over political elites, ultimately leading to adoption of more responsive macroeconomic policies.

Erol Taymaz, Associate Professor, Department of Economics,

Middle East Technical University

Kamil Yılmaz, Associate Professor, Koç University
Commission

on Growth and

Development

Montek Ahluwalia

Edmar Bacha

Dr. Boediono

Lord John Browne

Kemal Derviş

Alejandro Foxley

Goh Chok Tong

Han Duck-soo

Danuta Hübner

Carin Jämtin

Pedro-Pablo Kuczynski

Danny Leipziger, Vice Chair

Trevor Manuel

Mahmoud Mohieldin

Ngozi N. Okonjo-Iweala

Robert Rubin

Robert Solow

Michael Spence, Chair

Sir K. Dwight Venner

Ernesto Zedillo

Zhou Xiaochuan

The mandate of the

Commission on Growth

and Development is to

gather the best understanding

there is about the policies

and strategies that underlie rapid economic growth and poverty reduction.

The Commission's audience is the leaders of developing countries. The Commission is supported by the governments of Australia, Sweden, the Netherlands, and United Kingdom, The William and Flora Hewlett Foundation, and The World Bank Group. 